\title{
Riverine Flood Damage Assessment of Cultivated Lands along Chenab River Using GIS and Remotely Sensed Data: A Case Study of District Hafizabad, Punjab, Pakistan
}

\author{
Khurram Chohan1*, Sajid Rashid Ahmad1, Zia ul Islam1, Muhammad Adrees² \\ ${ }^{1}$ The Institute of Geology, University of the Punjab, Lahore, Pakistan \\ ${ }^{2}$ The Urban Unit, Urban Sector Planning and Management Services Unit (Pvt.) Ltd., Lahore, Pakistan \\ Email: ${ }^{*}$ khurramchohan2001@gmail.com, sajidpu@yahoo.com, ziamayo@gmail.com, idreesgis@gmail.com
}

Received 5 September 2015; accepted 18 October 2015; published 21 October 2015

Copyright (C) 2015 by authors and Scientific Research Publishing Inc.

This work is licensed under the Creative Commons Attribution International License (CC BY). http://creativecommons.org/licenses/by/4.0/

\section{(c) (i) Open Access}

\begin{abstract}
Flood is one of a kind of disasters which harms human and animal life around the globe. Pakistan has been observing massive floods for many years because of daily and seasonal variation in the temperature levels. Wheat, rice, sugarcane and cotton are major crops cultivated in Punjab region of Pakistan in which rice and sugarcane are mostly effected by floods. In this research paper, damage assessment of cultivated land in district Hafizabad along Chenab River has been calculated. Supervised Classification and Soil Adjusted Vegetation Index (SAVI) methods are applied. Pre-flood 2014, post-flood 2014, and pre-flood 2015 Landsat 8 images have been used to calculate the extent of damages to cultivated lands. Water, sand, silt, bare soil and vegetation are classified to identify damage. Results show that vegetation cover has plummeted to $50 \%$ after the arrival of flood 2014 in the Chenab. Similarly, $6.7047 \%$ of sand and $15.7339 \%$ of bare soil deposits have surfaced which have not yet been removed from fertile lands in 2015. 18.4376\% standing crop damage has been analyzed under this study. $14.0245 \%$ silt deposits have been calculated as post-flood effects. $46.4260 \%$ land has been cultivated in 2015 which is $15.5024 \%$ lower than 2014 cultivated land. Furthermore, field verification survey has given promising results and has a great correlation with satellite based recovery results.
\end{abstract}

\section{Keywords}

Flood, SAVI, Supervised Classification, GIS, Remote Sensing, Damage Assessment, Sand

\footnotetext{
${ }^{*}$ Corresponding author.
} 


\section{Introduction}

Flood is one of a kind of disasters which harms human and animal life around the globe [1]. A flood devastates not only the infrastructure of a country but also the health, water, sanitation and education, transportation, industrial, trade, agriculture and communication [2]. Flood chances have increased due to deforestation and development of human activities [3]. There is always pressure on both agricultural and natural resources due to the increase in population [4]. It is also certain that floods bring changes in land use and land cover [5]. The whole South Asia is vulnerable to extensive flooding. According to estimation, two hundred people have lost their lives during 2010 floods of Thailand [6]. Pakistan has been observing massive floods for many years because of daily and seasonal variation in the temperature levels. Pakistan is situated at the tropic of cancer that is why its climate is of continental type. Low to very low temperatures are observed in the north of Pakistan. Similarly, sea breezes along the coastal zone of Indian Ocean are contributing certain changes in meteorological trends in the country. Mercury starts raising in February and reaches to peak level in June. Heat loaded winds lift upwards because of light weight and create low pressure zone in the atmosphere. Humid winds coming from Indian Ocean rush towards low pressure zone of Punjab. Torrid winds and Lofty temperatures go for lowering moisture in the form of rainfall in Punjab Province. Pakistan falls in the South-West zone of Moon-Soon phenomenon [7]. This zone receives Moon-Soon rainfall from June to September. Maximum moisture is loaded off as Moon-Soon reaches to Pakistan [8].

Pakistan is an agricultural state and relies on its agricultural products. Excessive rainfall causes floods in the main streams effecting the land use and standing crops. Many crops are cultivated in Pakistan like wheat, rice, sugarcane and cotton among the bumper crops. Rice and sugarcane crops are under cultivation when the rivers receive heavy water from Moon-Soon thunderstorms across the country. Therefore, major tributaries are inundated and create havoc along the adjoining settlements and cultivated lands every year [9] [10]. Indus River, 3200 kilometers long, is the largest river of Pakistan. Therefore, it has maximum flood potential. It sustained heavy flood of 0.96 million cusecs in 2010 and the similar example of Chenab River is available as a specimen to check the capacity of Pakistani rivers. The amalgam of Jehlum and Chenab River at Trimmu headwork has contributed maximum water to the downstream areas in the past floods [11]. Similarly, heavy damage is extended to the rice paddies due to water, silt, and sand deposits.

The damages of flood loss are calculated by affected area, population and farmland. It is also essential to conduct an evaluation procedure to examine their predicted results against the field measured data [12]. Therefore, pre-flood measures are taken and response is extended to the flood prone areas. Next, post-flood recovery cycle is exercised to rehabilitate flood hit zones [13]. Acquired satellite images should be cloud-free to image the ground condition of flood [14]. Riverine floods oftentimes erode river banks and take away huge agricultural lands along with it [15] [16]. However, deposits contribute destruction to neighboring standing crops as well [17]. These deposits may either enhance the fertility of crop lands or completely destroy agricultural lands for longer period as if sand is deposited [18].

In the recent flood of Pakistan 2014, approximately four to five feet sand deposits have been observed in the crop lands of Hafizabad District. Farmers are retrieving their agricultural lands from heavy sand deposits but it is still uncertain that how much land is recovered from sand deposits. Therefore, GIS and Remote Sensing data can be served as analytical and predicting tools for planning of agricultural development and to test the results of various development decisions before they can be used in the landscape [19]. Significance of accurate mapping system is increased during floods to control social and economic losses. Timely recognition of flood prone areas can save human lives and capital by early warning. Nowadays, recent techniques like GIS, GPS and Remote Sensing have been assisting flood disaster managers to develop accurate flood maps with improved hardware and software packages at a reasonable cost [20].

\section{Data and Methods}

\subsection{Study Area}

Hafizabad is the district of Punjab Province Pakistan. It is bounded by River Chenab in the eastern side and Sagar Kalan Gadirabad Link Canal in the western side. The river Chenab separates it from district Mandi Bahauddin. Hafizabad and Pindi Bhattian are its Tehsils as shown in Figure 1. Geographical extent of the study area is between $73^{\circ} 1^{\prime} 10.48^{\prime \prime} \mathrm{E}, 32^{\circ} 20^{\prime} 13.54 " \mathrm{~N}$ and $73^{\circ} 46^{\prime} 15.68^{\prime \prime} \mathrm{E}, 31^{\circ} 56^{\prime} 15.34^{\prime \prime} \mathrm{N}$. Being among the agricultural areas of 


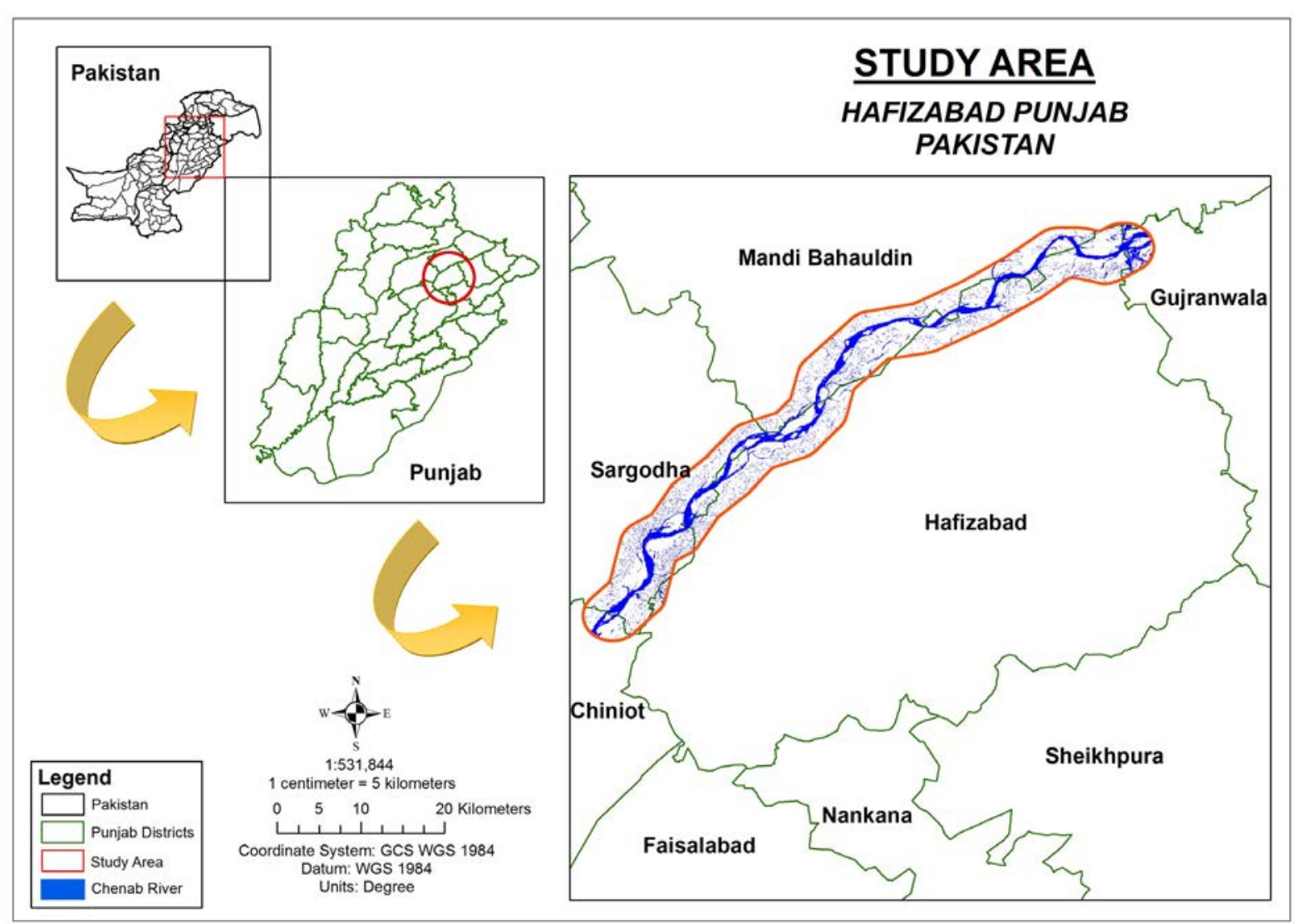

Figure 1. Area of District Hafizabad, Punjab, Pakistan.

Punjab, district Hafizabad is popular for rice, wheat, sugarcane, and cotton production. Rice production industry did exist even before the resurrection of Pakistan. The district has been facing flood damages since long time but the flood of 2014 is the deadliest ever flood after the flood of 1992 in its flood history. Qadirabad headwork is situated on the River Chenab which lies in the North of Hafizabad.

\subsection{Data Sources}

In order to achieve research objectives, Landsat 8 data have been acquired to monitor pre-flood and post-flood activities along Chenab River, District Hafizabad. Landsat 8 data is updated after every 16 days and access to latest images are made possible around the globe. Surveys have been important and significant part of the study area during this study. Therefore, GPS surveys have been conducted to identify the signature patterns of water, bare soil, healthy vegetation, sand deposits, silt deposits, and damage lands shown in Table 1 during flood activity 2014. Tehsil and District boundaries have also been marked to identify the extent of damages to cultivated lands along Chenab River. To increase understanding about Chenab River and surrounding places, a complete survey has been completed to identify local landmarks.

\subsection{Methodological Framework}

Image classification is the process to automatically arrange pixels into land cover and land use classes [21]. In this research, Supervised Classification technique has been used to analyze land cover along Chenab River [22]. Supervised classification uses sample training areas to highlight accurate pattern of water, sand, and soil which are also verified by ground validation technique. Study area is divided into four sections in order to have better visual results. Each section of the study area is approximately 21 kilometers long and 9 kilometers wide and all four sections collectively cover 6 kilometers wide buffer zone study area of Chenab River. Landsat 8 satellite images have been classified to identify land use and land cover of 6 kilometers buffer zone study area along 
Table 1. Training sites for image classification.

\begin{tabular}{cccc}
\hline Sr. No. & Class Type & Latitude & Longitude \\
\hline 01 & Water & 32.3726 & 74.8826 \\
02 & Sand & 32.3074 & 73.6239 \\
03 & Silt & 32.2839 & 73.6333 \\
04 & Healthy Vegetation & 32.0679 & 74.6936 \\
\hline
\end{tabular}

Chenab River, Hafizabad. Image classification process has been completed using Erdas Imagine 2014 software. Spectral information of water, sand, silt, healthy vegetation, and damage vegetation has been used to complete the process of Spectral Pattern Recognition. Pre-flood, post-flood and satellite image of 2015 of Chenab River are classified to delineate water, sand, and silt damages to cultivated lands along the river.

Soil Adjusted Vegetation Index (SAVI) is being used as an index to calculate vegetation in an efficient way by reducing the effects of soil and atmosphere. This technique has been used to reduce soil noise in this research to highlight the lands having potential to grow vegetation [23]. This index uses red and infrared wavelengths to calculate minor vegetation cover using the addition of constant value in NDVI equation as shown in Equation (1). During the development phase of this index, various soil reflectance wavelengths were accessed through adding constant values of " $\mathrm{L}$ " from 1 to 100 . Thereby, light color soil to dark color soil values were developed. The same index was tested upon various vegetation densities. If the value of "L" becomes zero, its mean that there is high vegetation available on the observed landscape. Similarly, if the value of "L" becomes 1, it's mean that there is no vegetation available on the observed landscape. $\mathrm{L}=0.5$ works well in most of the situations [24] [25].

$$
\mathrm{SAVI}=\mathrm{NIR}-\mathrm{RED} /(\mathrm{NIR}+\mathrm{RED}+\mathrm{L}) *(1+\mathrm{L})
$$

where:

NIR $=$ Near Infrared Wavelength;

RED $=$ Red Wavelength;

$\mathrm{L}=$ Soil Brightness Correction Factor.

Land damages due to the effects of flood 2014 in Chenab River have been identified and measured through using SAVI and Supervised Classification Methods. Complete methodological frame work is shown in Figure 2 and Figure 3.

\section{Results and Discussion}

\subsection{Supervised Classification of Land along Chenab River}

Study area is classified into water, sand, silt, bare soil, destroyed vegetation, and healthy vegetation using supervised classification as shown in Figures 4-7. It has been analyzed that there were large cultivated lands before when flood inundated the area and deposited. River was also flowing at its normal level before flood. Massive flood water changed the normal water course and damaged not only standing crops but also completely washed away hundreds of acre land with its erosional thrust. Total area of each class is calculated shown in Table 2 which in whole indicates that vegetation cover has plummeted to $50 \%$ soon after the arrival of flood 2014 in the Chenab. Similarly, sand (6.7047\%) and bare soil (15.7339\%) deposits are surfaced which have not yet been removed from fertile lands in 2015. 18.4376\% standing crop damage has been analyzed under this study. $14.0245 \%$ silt deposits have been calculated as post-flood effects. $46.4260 \%$ land has been cultivated in 2015 which is $15.5024 \%$ lower than 2014 cultivated land. Statistics have also shown a significant increase in sand and bare soil deposits as water is receded throughout the study area in 2015 as shown in Figure 8.

\subsection{Identification of Cultivated Lands along Chenab River Using SAVI}

SAVI technique has been utilized to separate cultivated, uncultivated lands, and water across the study area of Chenab River. Flood damages have been accessed through the temporal changes in the vegetation cover. Statistical data calculated through satellite images have shown that water has destroyed not only cultivated lands 


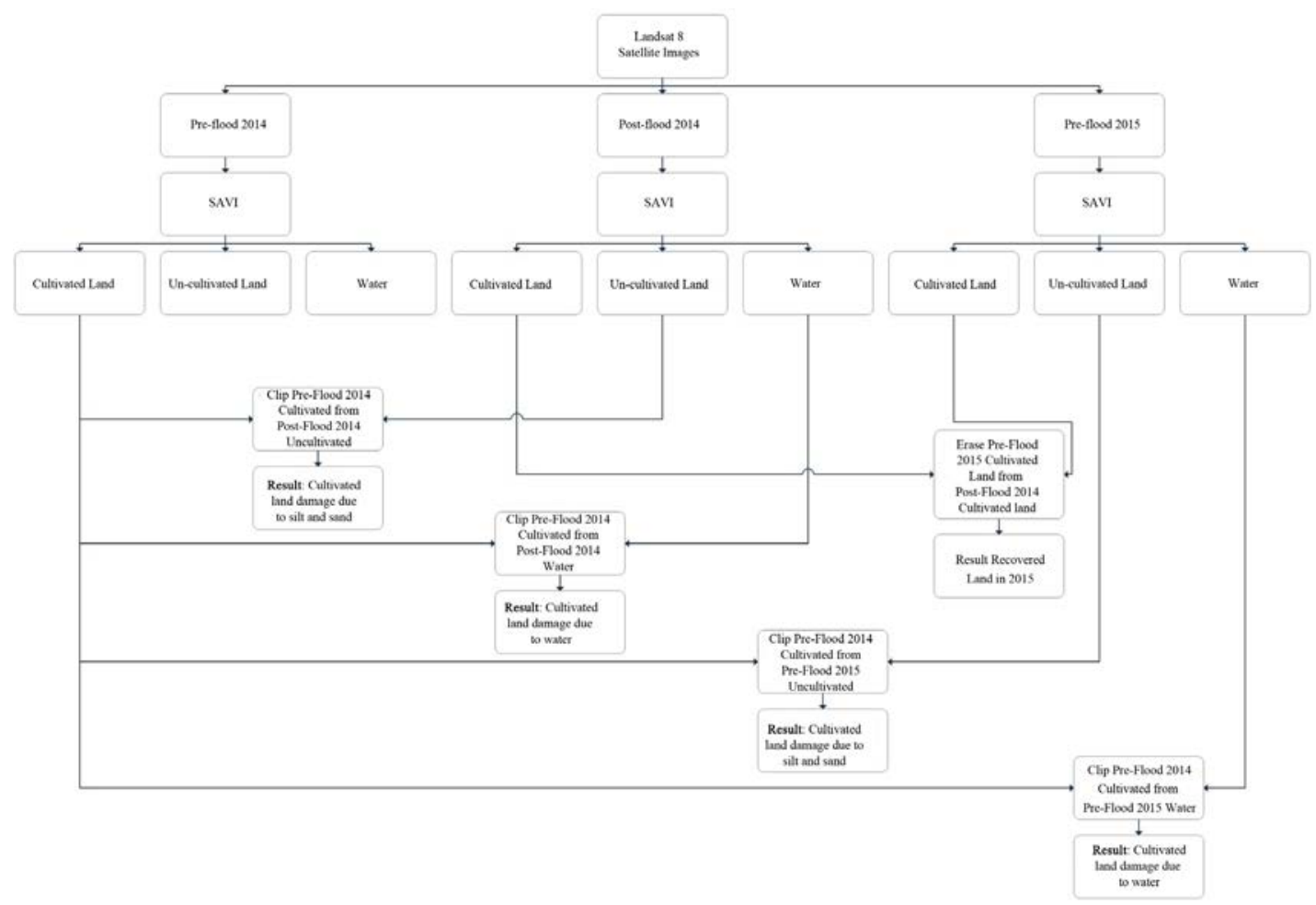

Figure 2. Methodology adopted using Soil Adjusted Vegetation Index (SAVI) upon pre-flood 2014, post-flood 2014 \& pre-flood 2015 datasets.

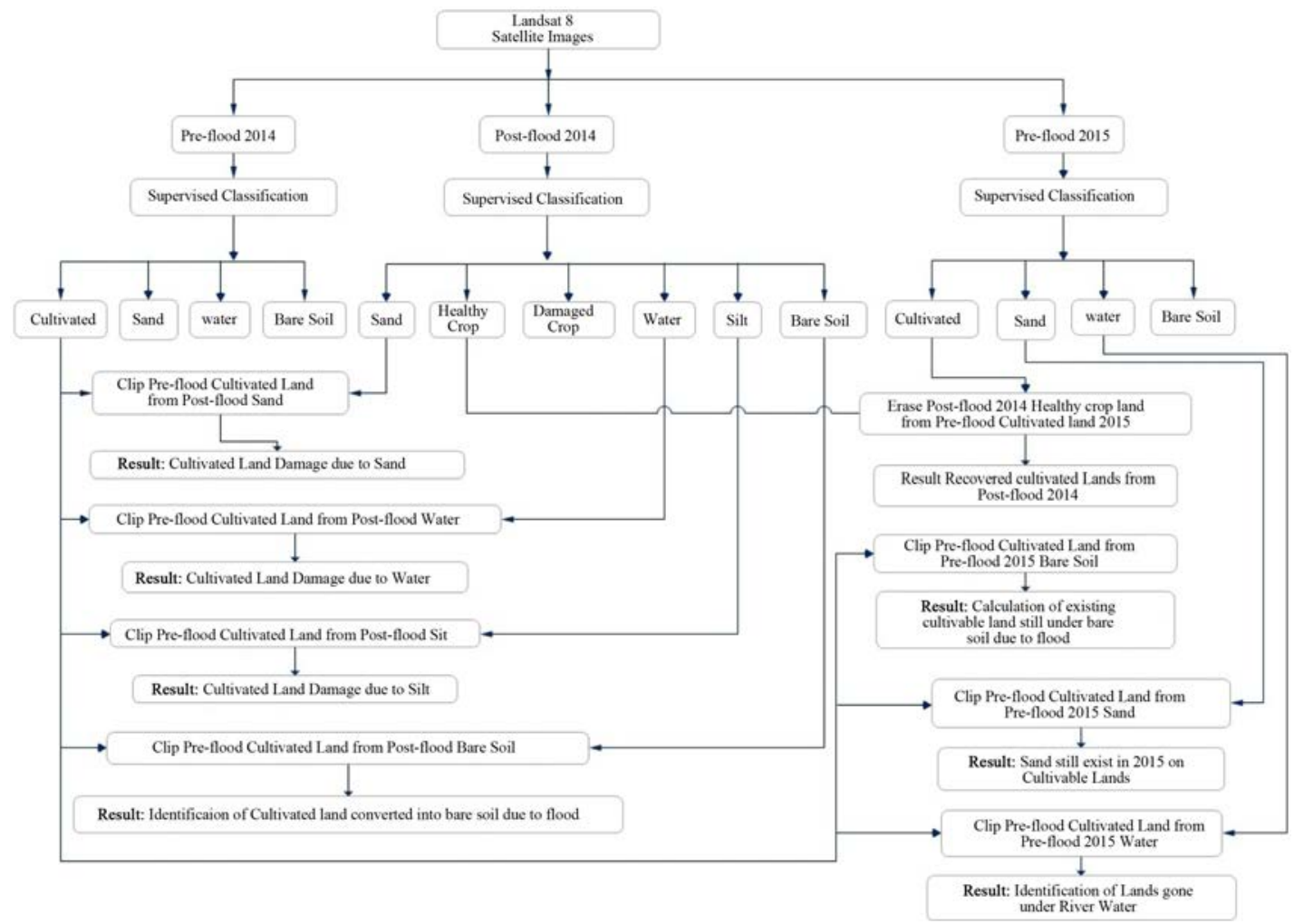

Figure 3. Methodology adopted using supervised classification upon pre-flood 2014, post-flood 2014 \& preflood 2015 datasets. 


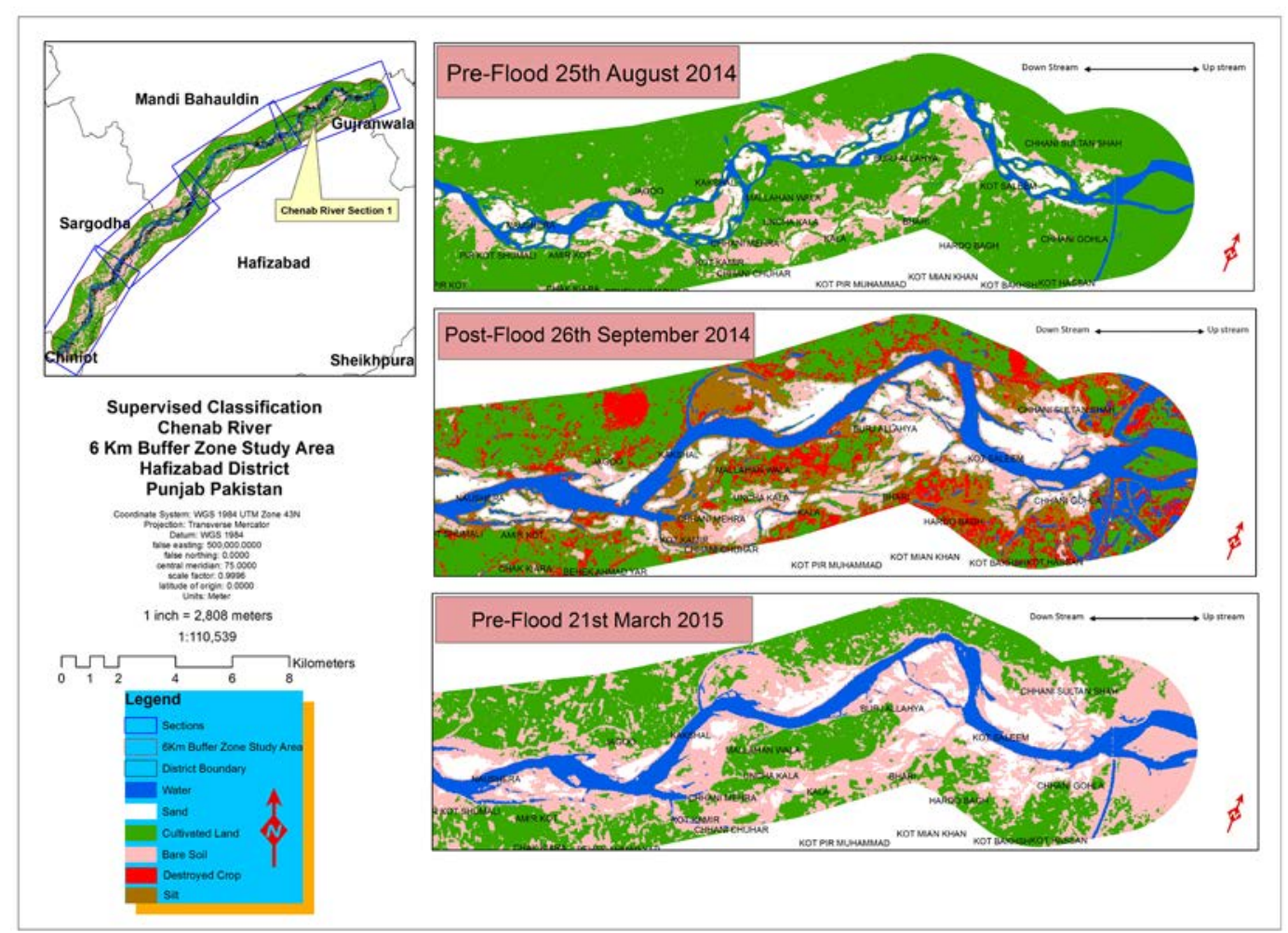

Figure 4. Supervised classification, section 1, Chenab River 6 km buffer zone study area, Hafizabad District, Punjab, Pakistan.

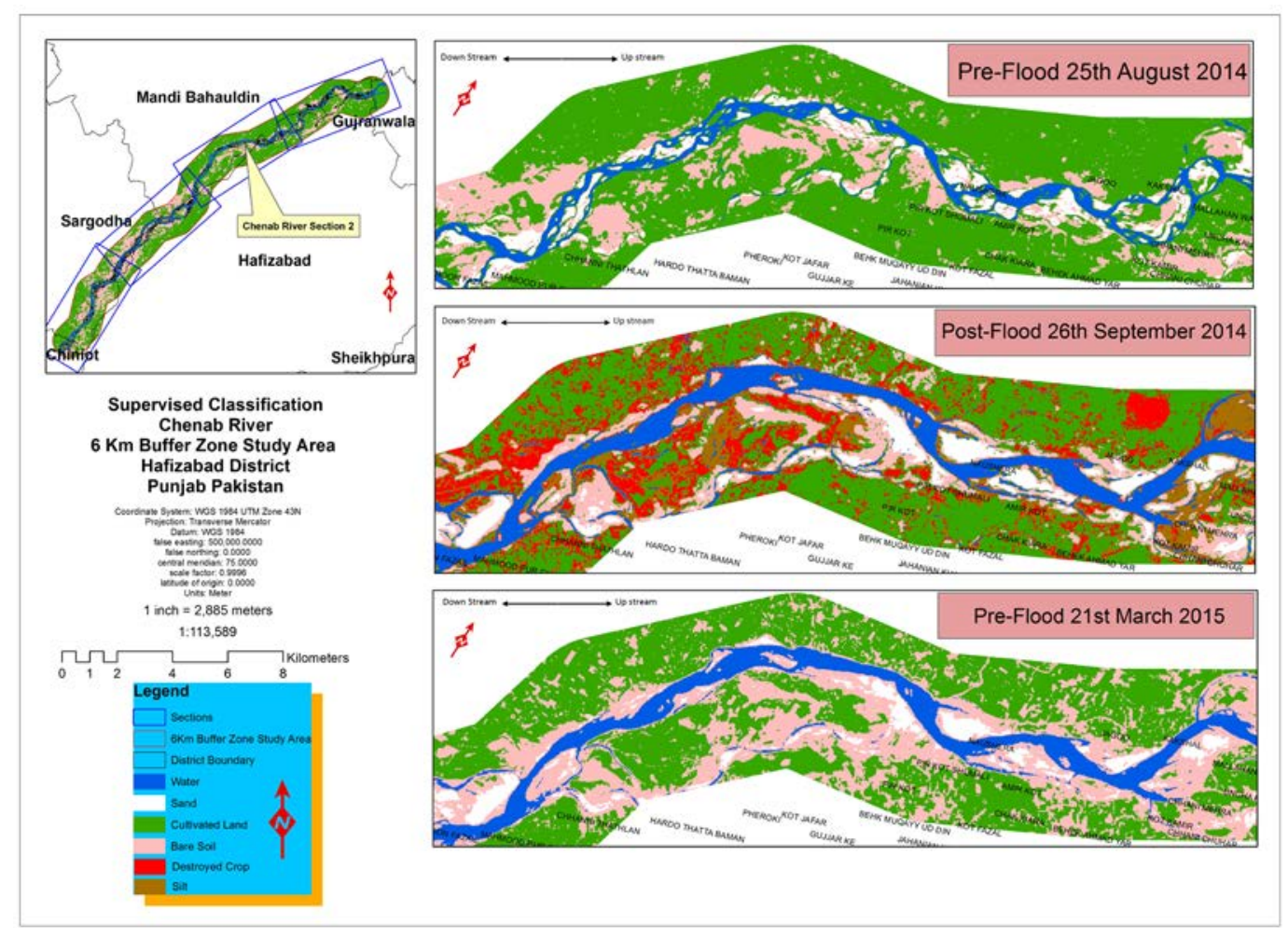

Figure 5. Supervised classification, section 2, Chenab River 6 km buffer zone study area, Hafizabad District, Punjab, Pakistan. 


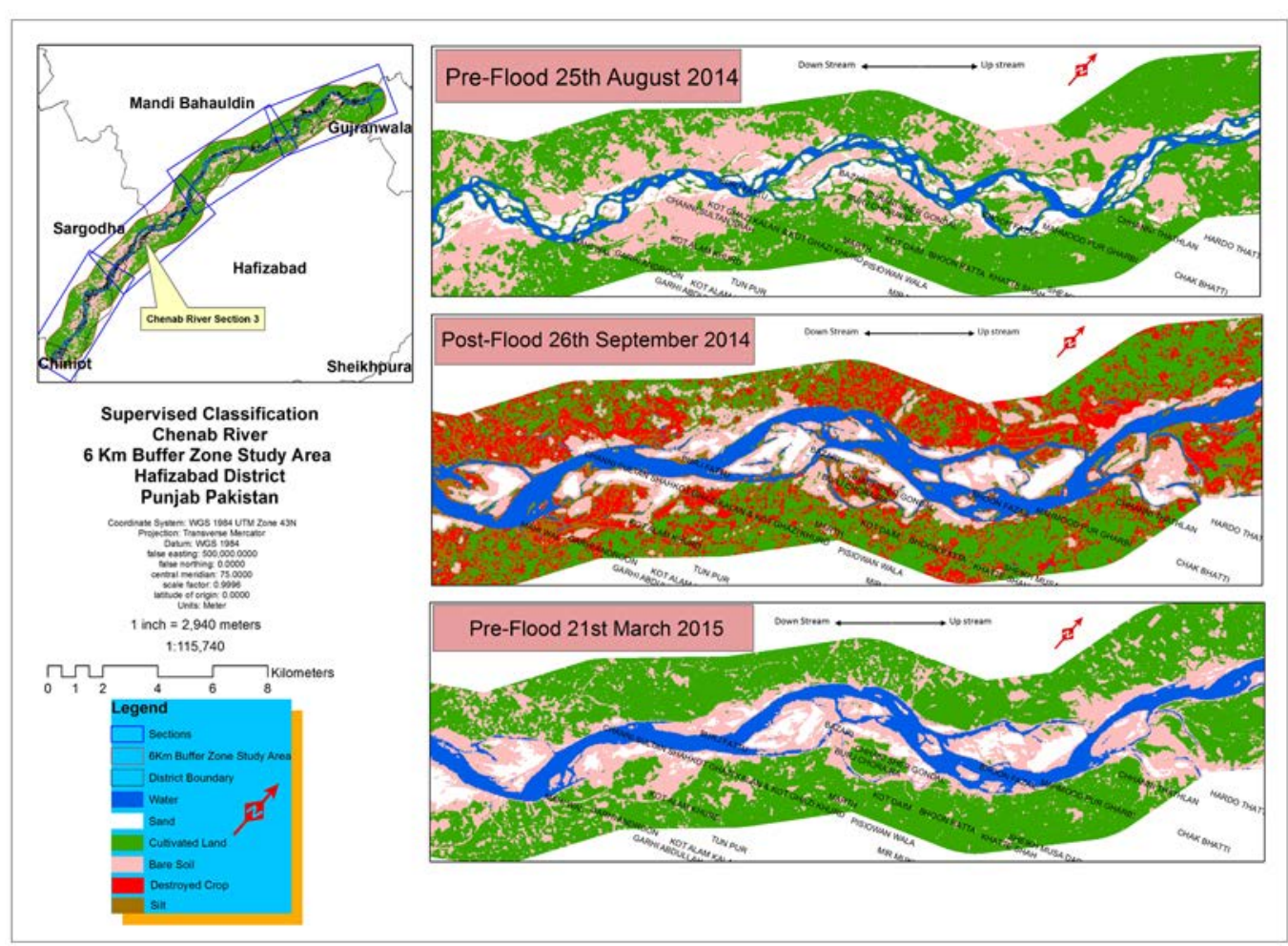

Figure 6. Supervised classification, section 3, Chenab River 6 km buffer zone study area, Hafizabad District, Punjab, Pakistan.

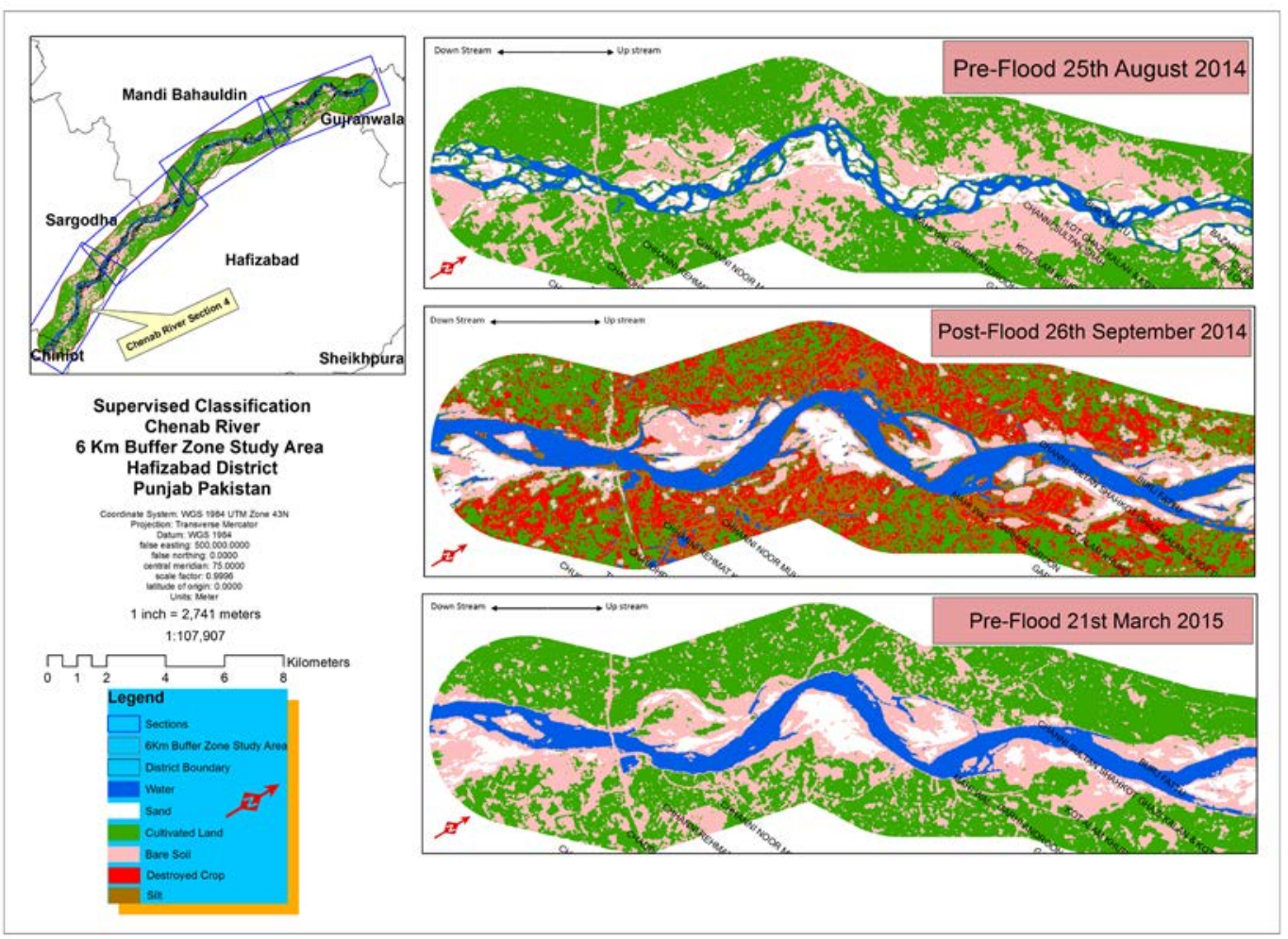

Figure 7. Supervised classification, section 4, Chenab River $6 \mathrm{~km}$ buffer zone study area, Hafizabad District, Punjab, Pakistan. 


\section{Supervised Classification Results Bar Graph}

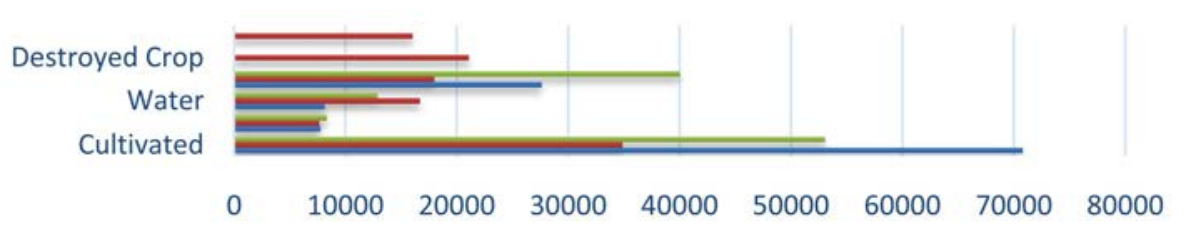

घ Pre Flood 21st March, 2015 a Post-flood on 26th September,2014

a Pre-flood on 25th August, 2014

Figure 8. Supervised classification results Bar Graph.

Table 2. Area calculation of all LAND Use Land Cover (LULC) classes using supervised classification in acre.

\begin{tabular}{cccccccc}
\hline & Healthy Crop & Sand & Water & Bare Soil & $\begin{array}{c}\text { Destroyed } \\
\text { Crop }\end{array}$ & Silt & Total \\
\hline Pre-Flood & $70,799.37369$ & 7760.31378 & 8135.804039 & $27,629.01629$ & - & - & $114,324.5078$ \\
Aug. 2014 & $(61.9284 \%)$ & $(6.7879 \%)$ & $(7.1164 \%)$ & $(24.1671 \%)$ & - & & \\
Post-Flood & $34,872.310398$ & 7665.145034 & $16,687.073418$ & $17,987.726912$ & $2,1078.773777$ & $16,033.50376$ & $114,324.5333$ \\
Sep. 2014 & $(30.5029 \%)$ & $(6.7047 \%)$ & $(14.5962 \%)$ & $(15.7339 \%)$ & $(18.4376 \%)$ & $(14.0245 \%)$ & \\
Pre-Flood & $53,076.36591$ & 8321.60695 & $12,897.33654$ & $40,029.1984$ & & - & $11,4324.5078$ \\
March. 2015 & $(46.4260 \%)$ & $(7.2789 \%)$ & $(11.2813 \%)$ & $(35.0136 \%)$ & & - & \\
\hline
\end{tabular}

shown in Table 3 but also extended damages to uncultivated lands across the study area. Using Landsat 8 satellite images of pre-flood, post-flood, and pre-flood 2015, three classes have been generated to analyze the distribution of vegetated and none-vegetated lands with the distribution of water using SAVI technique as it is shown in Figure 9. Pre-flood situation is shown in Figure 10 where $59.4106 \%$ cultivated and $32.1672 \%$ uncultivated lands have been calculated. As the flood hit the study area, $25.9785 \%$ cultivated land decreased and $19.8065 \%$ uncultivated land has increased shown in Figure 11 because of deposition. Figure 12 shows that 14.1272\% from $25.9785 \%$ previously destroyed cultivated land is reinstated. But $11.8513 \%$ agricultural land parcels are still under heavy sandy deposits and water.

\subsection{Temporal Change in the Chenab River Flow Direction}

Hundreds of villages have observed damages during flood 2014 along Chenab River due to the change of water flow direction which is the part of fluvial geomorphic system. Change in the main water body of the river is cross checked with the dataset of 2015 in order to analyze up-to-date scenario as shown in the Figure 13. Maximum change in the water direction has been observed near Headwork Qadirabad. Therefore, Maximum damage is witnessed in the vegetated lands nearer to the headwork Qadirabad. The Surge was so high that it inundated the maximum active flood plain. Figure 14 shows pre-flood 2014 and pre-flood 2015 water flow condition under which this is significant that heavy flood erosion has eaten agricultural lands.

\subsection{Fluvial Erosion along Chenab River}

During flood 2014, Chenab River banks have eroded and converted into water channel. Numbers of sites have been observed through physical surveys that erosion has damaged cultivated lands. Post-flood 2014 erosion is mapped using SAVI shown in Figure 15. Post-flood 2015 image dataset has been utilized to monitor the rate of current damage and recovery of lands from erosion. It has been observed that vast area is either under water or completely washed away in water as shown in Figure 16. Meandering has been the main cause of erosion at Chenab River banks because water was flowing on its outer side which has deepened the channel. Therefore, lateral erosion is observed along its banks as it is shown in Figure 17 using supervised classification. Deposition 
Table 3. Area calculation through Soil Adjusted Vegetation Index (SAVI) in acre.

\begin{tabular}{ccccc}
\hline & Cultivated & Uncultivated & Water & Total \\
\hline \multirow{2}{*}{ Pre-Flood Aug. 2014 } & $67,685.56292$ & $36,647.63607$ & 9595.043227 & $113,928.2422$ \\
& $(59.4106 \%)$ & $32.1672 \%$ & $(8.4220 \%)$ & \\
Post-Flood Sep. 2014 & $38,112.52663$ & $59,249.87043$ & $16,637.22567$ & $113,999.6227$ \\
& $(33.4321 \%)$ & $(51.9737 \%)$ & $(14.5941 \%)$ & \\
Pre-Flood March. 2015 & $54,178.94143$ & $41,773.31404$ & $17,966.37825$ & $113,918.6337$ \\
& $(47.5593 \%)$ & $(36.6694 \%)$ & $(15.7712 \%)$ & \\
\hline
\end{tabular}

\section{Soil Adjusted Vegetation Index (SAVI) Results Bar Graph}

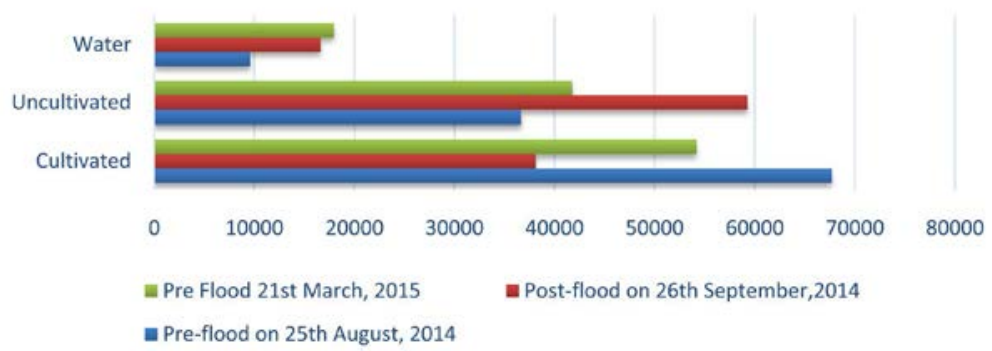

Figure 9. Soil Adjusted Vegetation Index (SAVI) bar graph.
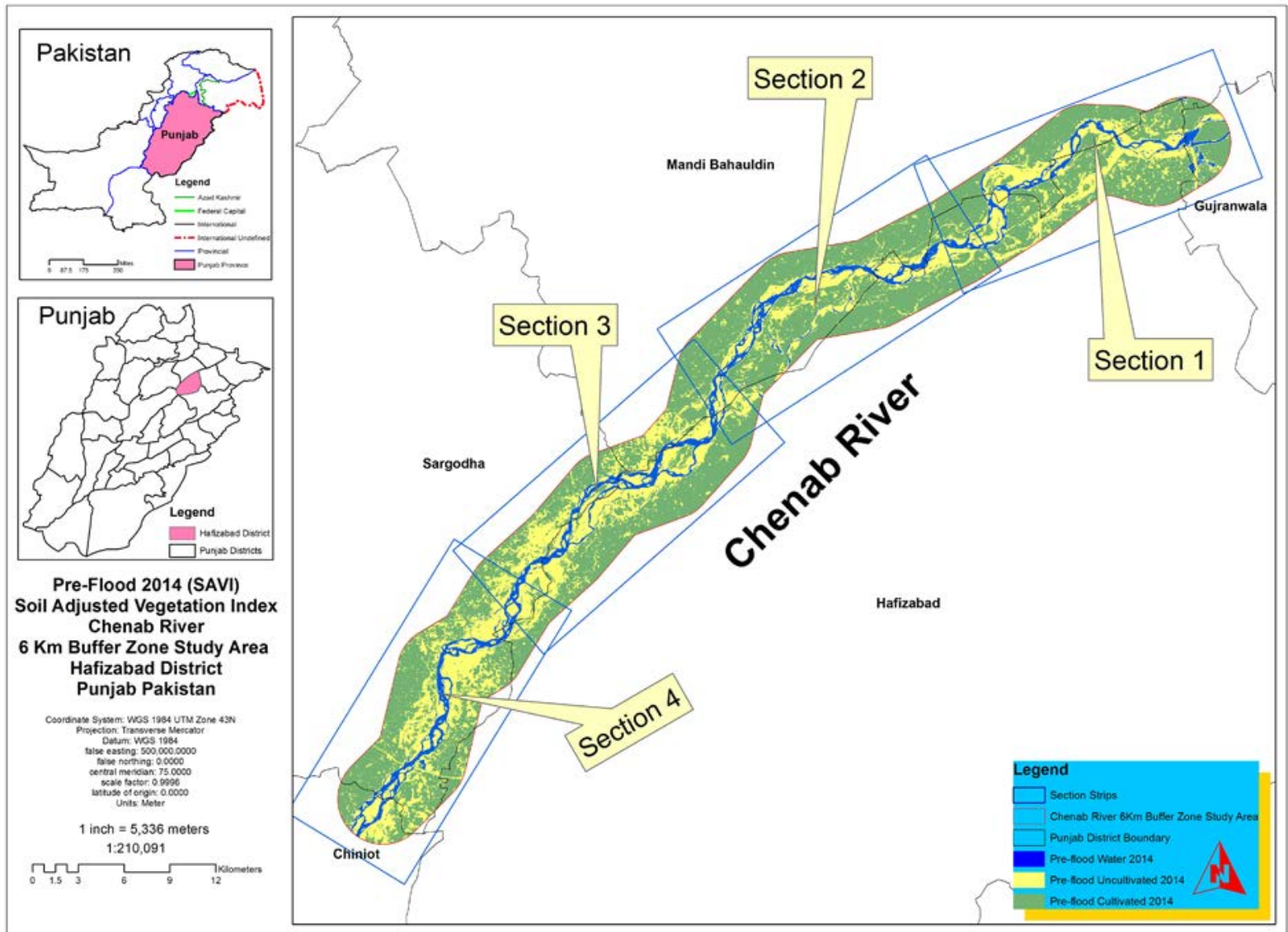

Figure 10. Pre-flood 2014, Soil Adjusted Vegetation Index (SAVI), Chenab River 6 km buffer zone study area, Hafizabad District, Punjab, Pakistan. 


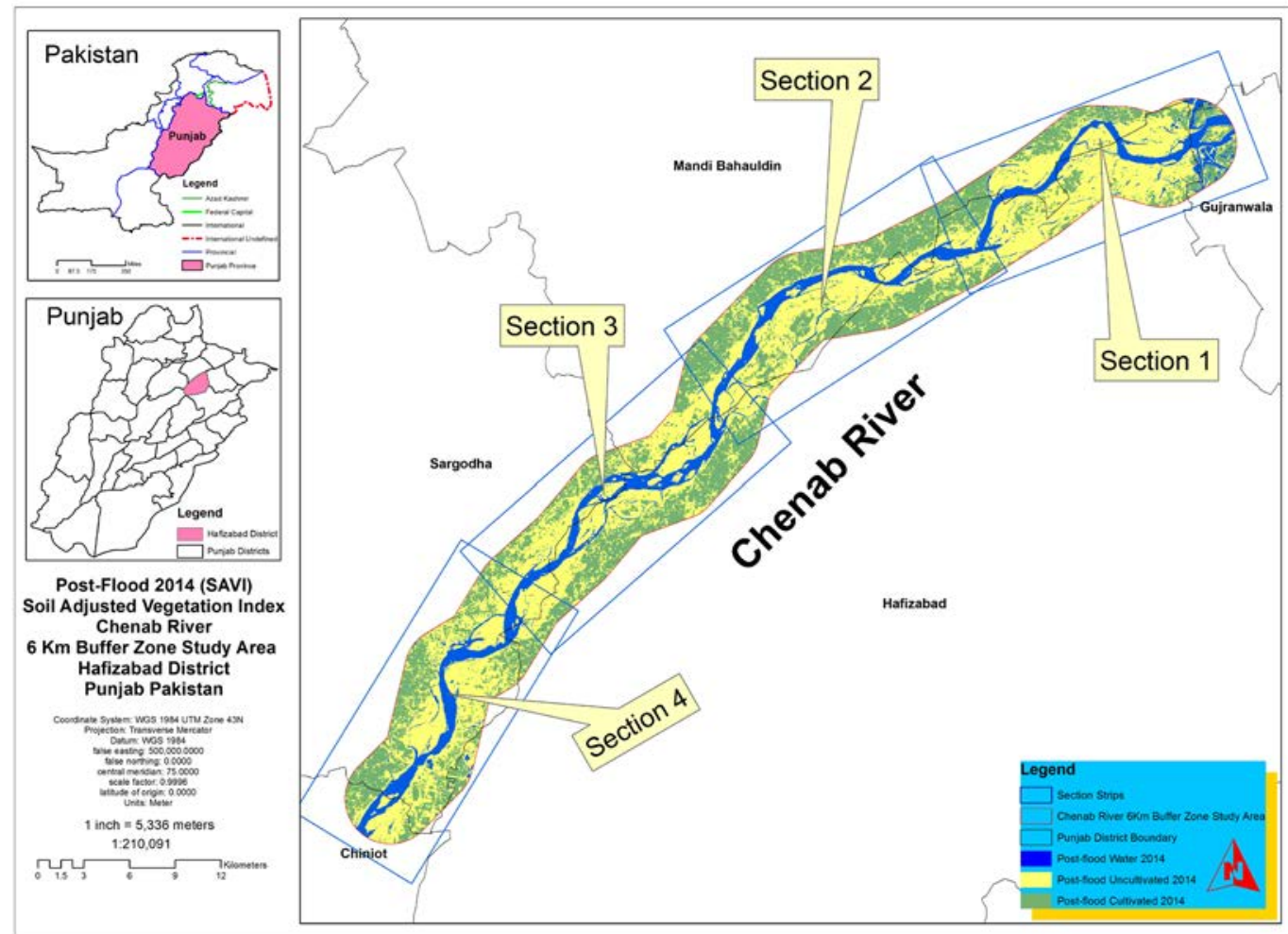

Figure 11. Post-flood 2014, Soil Adjusted Vegetation Index (SAVI), Chenab River 6 km buffer zone study area, Hafizabad District, Punjab, Pakistan.

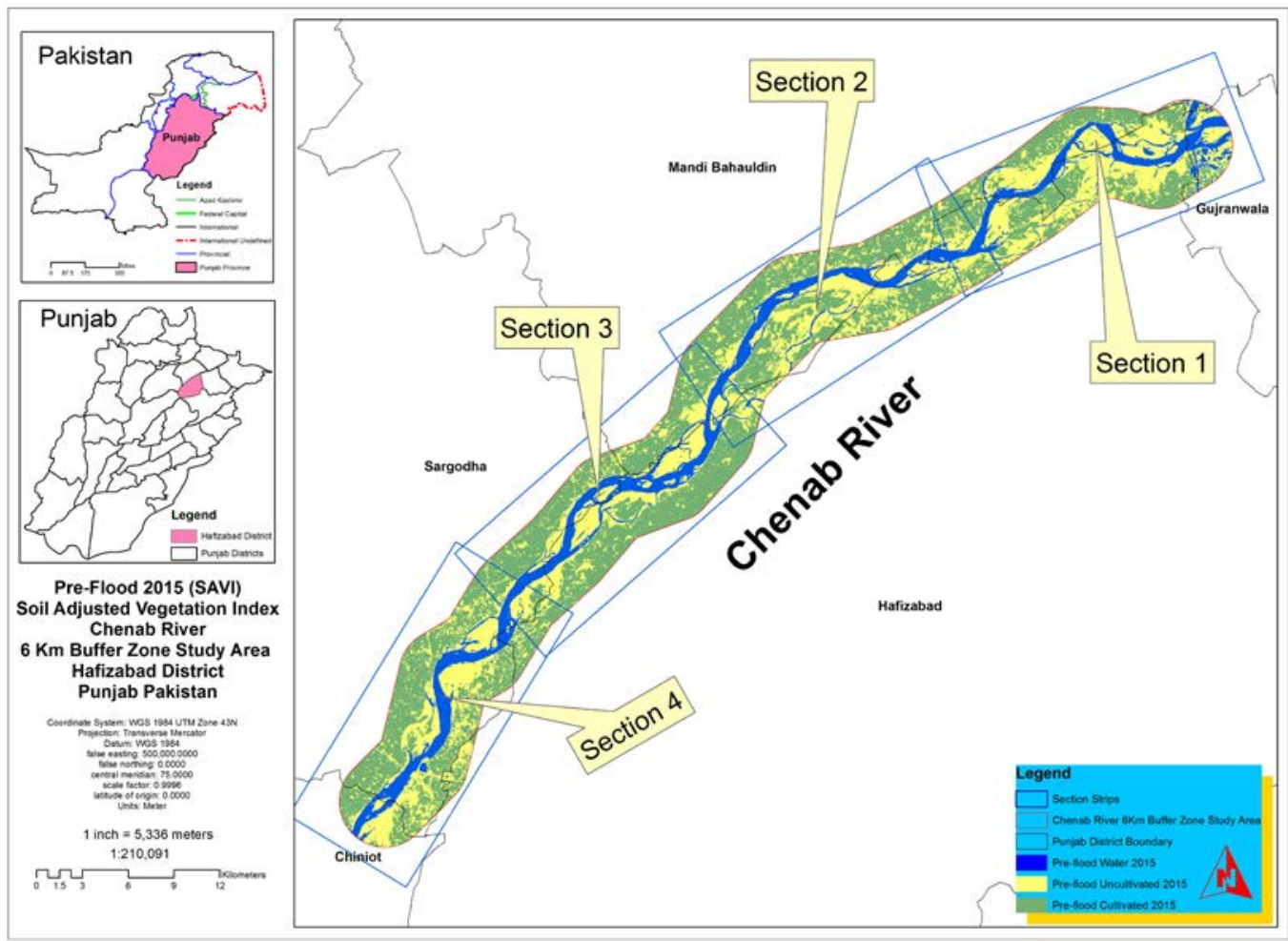

Figure 12. Pre-flood 2015, Soil Adjusted Vegetation Index (SAVI), Chenab River 6 km buffer zone study area, Hafizabad District, Punjab, Pakistan. 


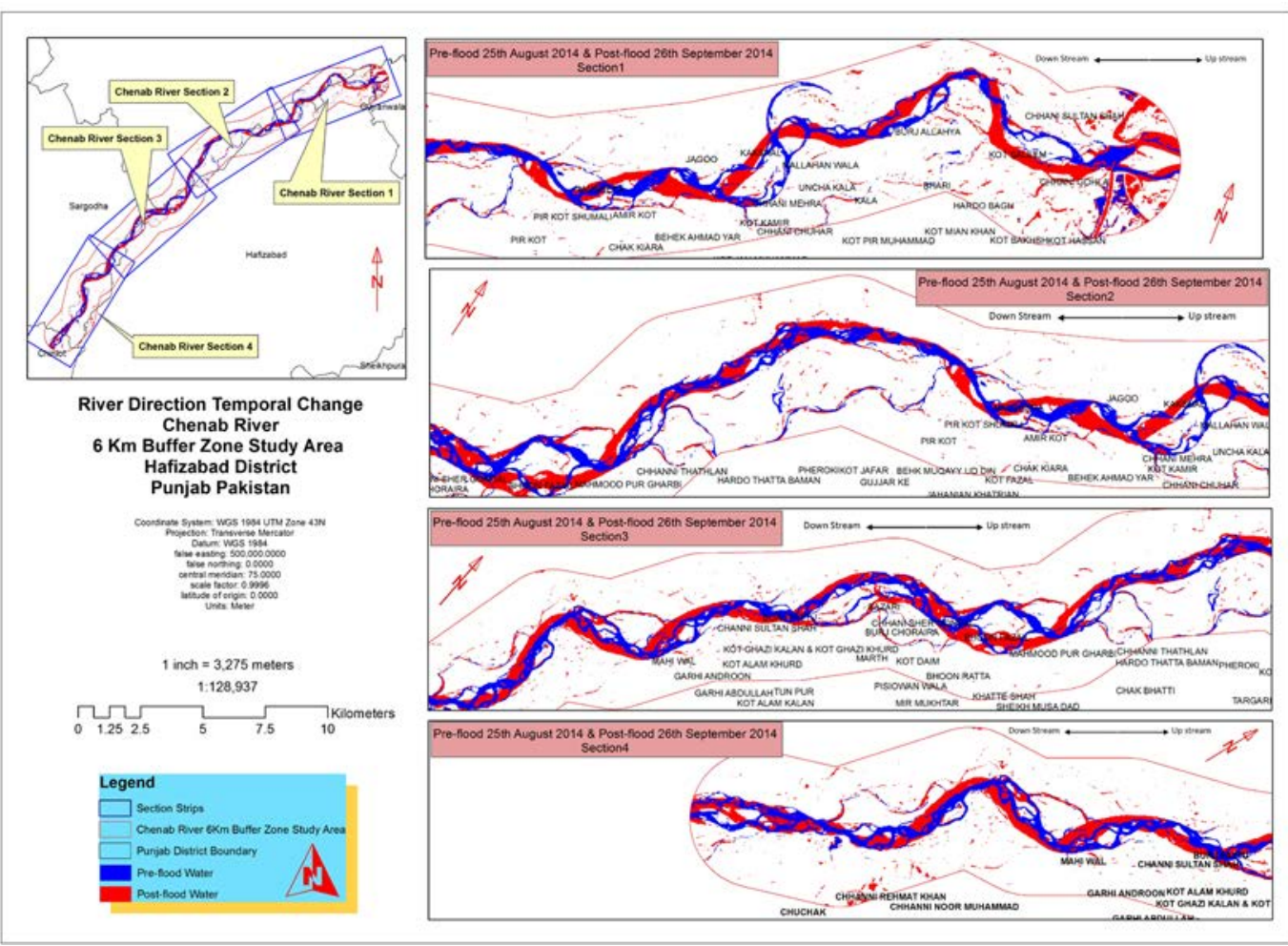

Figure 13. River direction temporal change, pre-flood 2014 \& post-flood 2014, Chenab River 6 km buffer zone study area, Hafizabad District, Punjab, Pakistan.

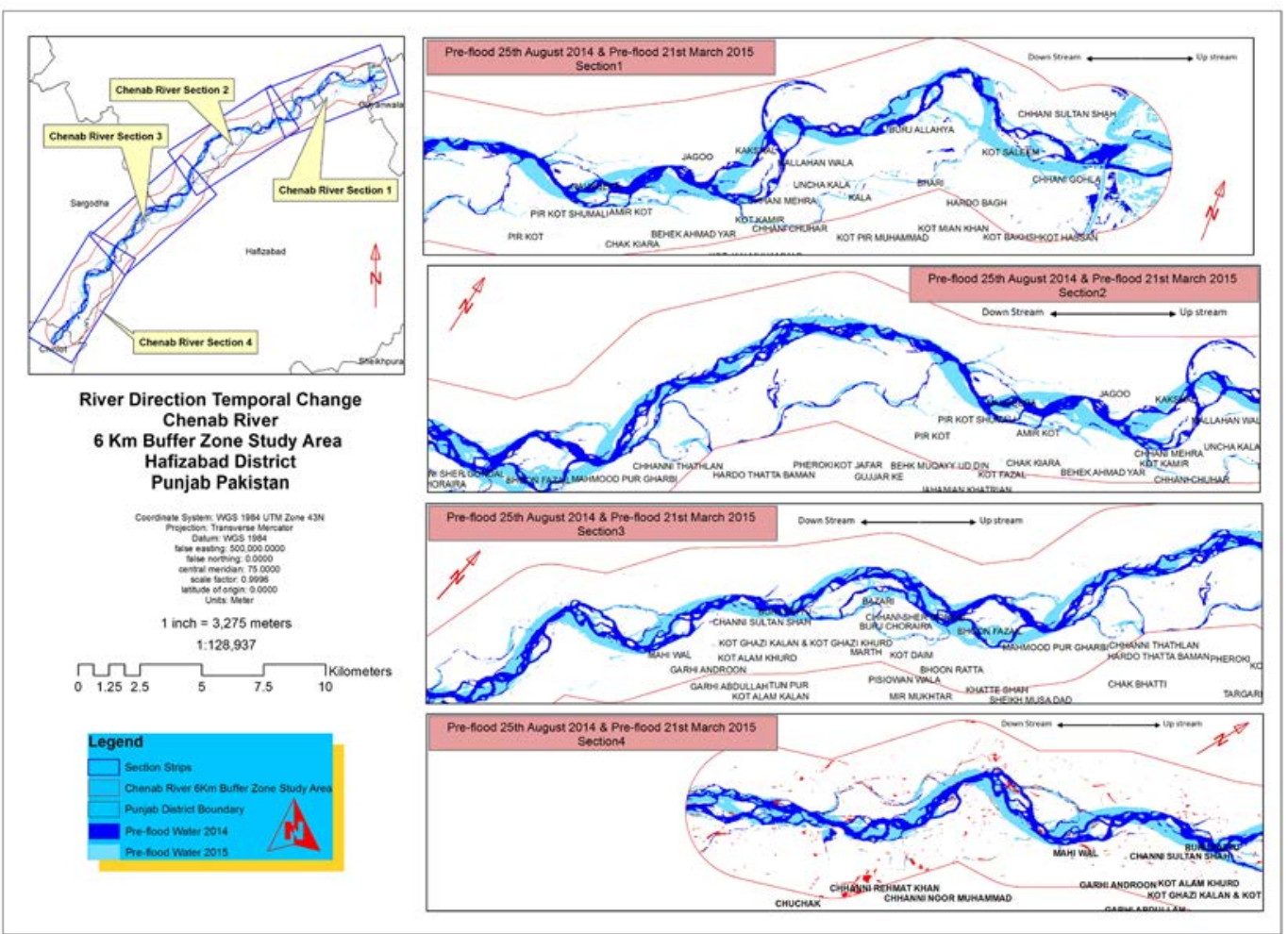

Figure 14. River direction temporal change, pre-flood 2014 \& Post-flood 2015, Chenab River 6 km buffer zone study area, Hafizabad District, Punjab, Pakistan. 


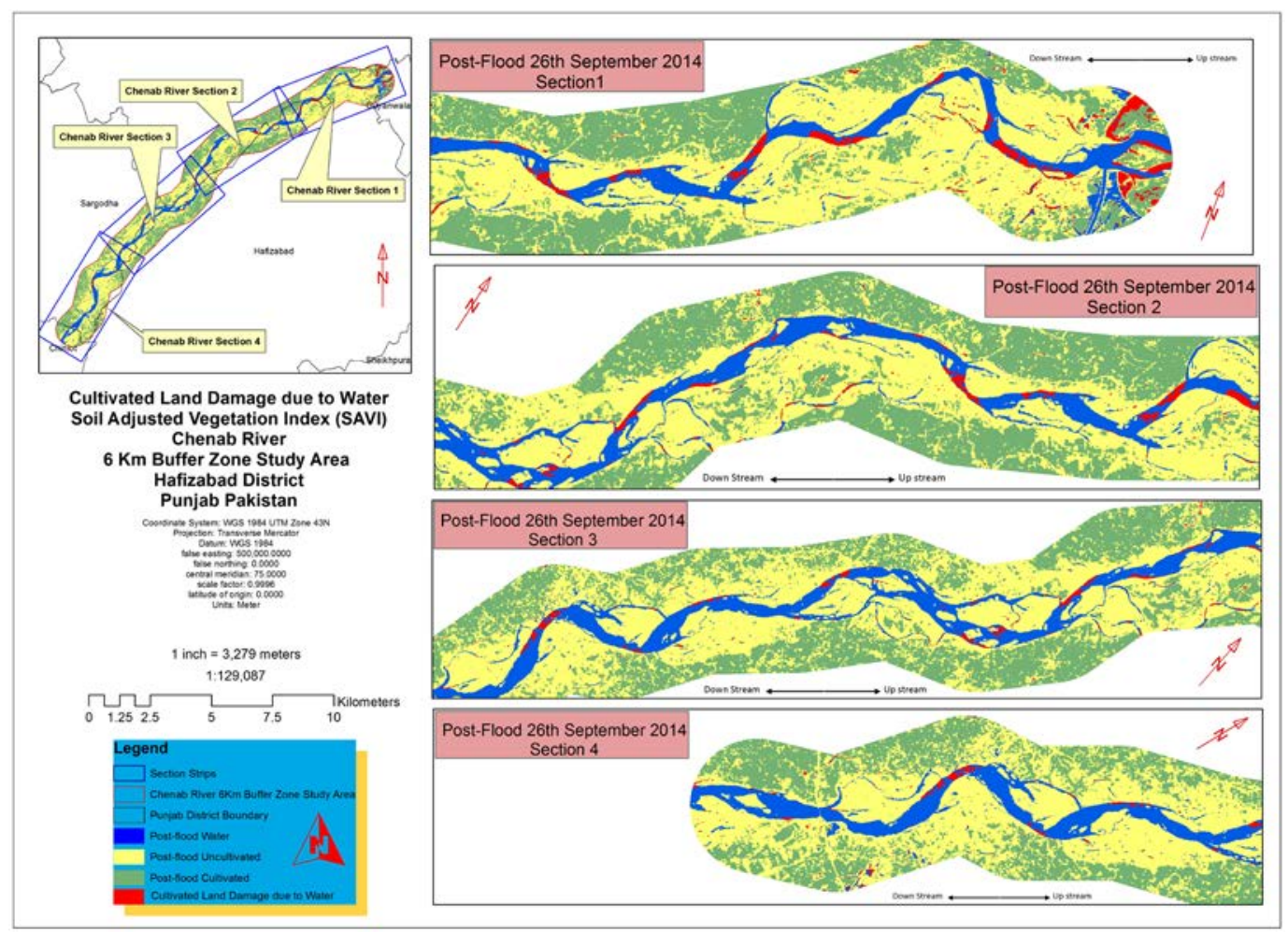

Figure 15. Cultivated land damage due to water, post-flood 2014, Soil Adjusted Vegetation Index (SAVI), Chenab River 6 km buffer zone study area, Hafizabad District, Punjab, Pakistan.

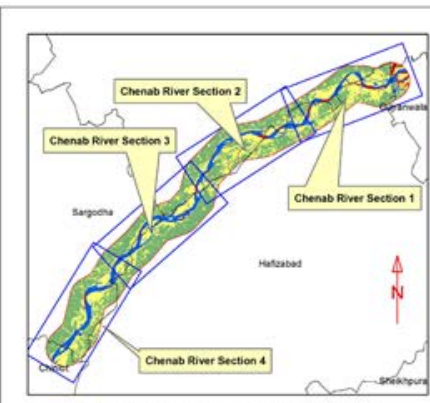

Flood Eaten Lands 2015 Scenario
Soil Adjusted Vegetation Index (SAVI)

Chenab River

$6 \mathrm{Km}$ Buffer Zone Study Area

Hafizabad District

Punjab Pakistan

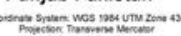

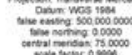

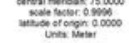

1 inch $=3,279$ meters 1:129,087
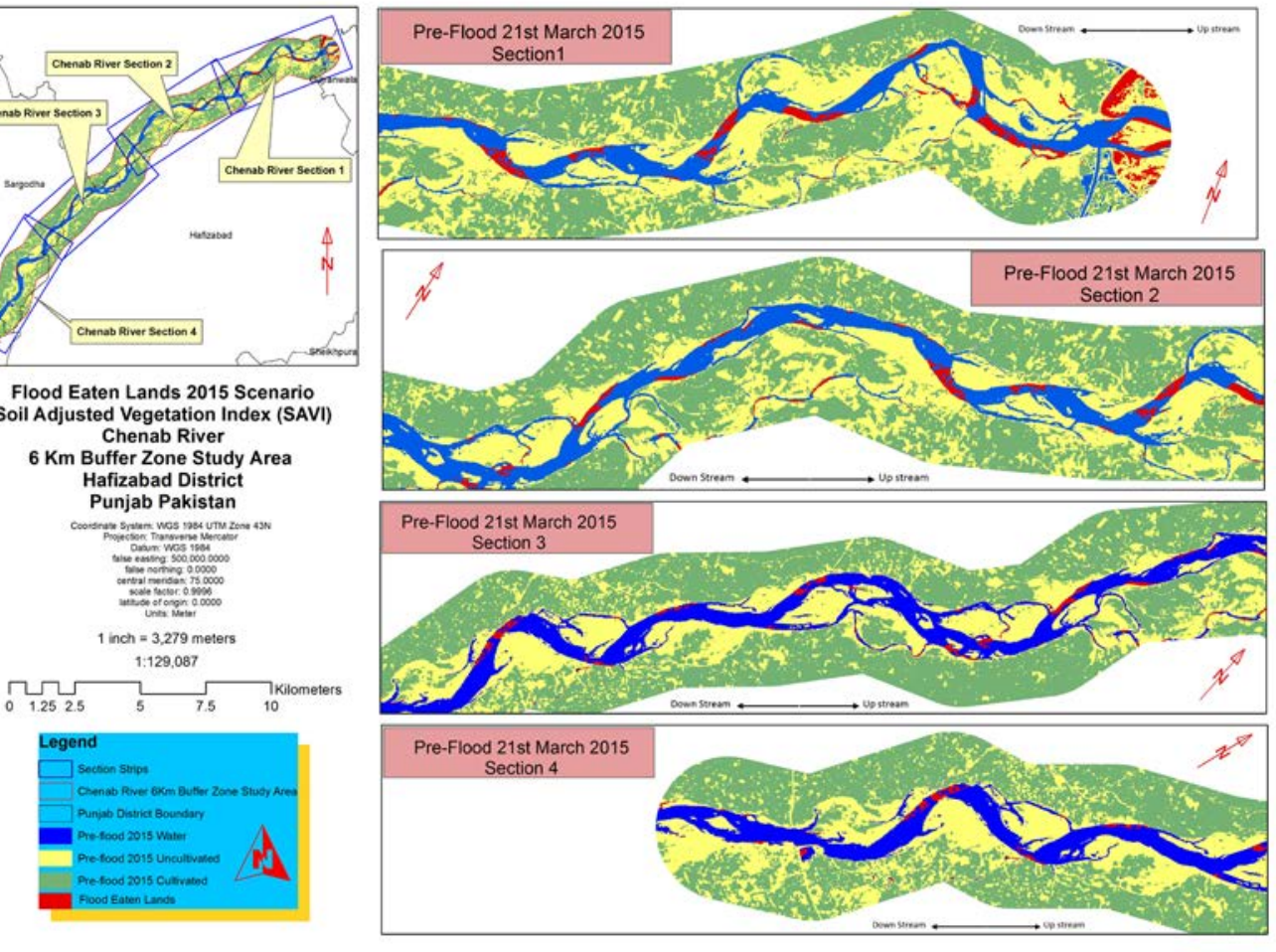

Figure 16. Flood eaten lands 2015 scenario post-flood 2015, Soil Adjusted Vegetation Index (SAVI), Chenab River 6 km buffer zone study area, Hafizabad District, Punjab, Pakistan. 


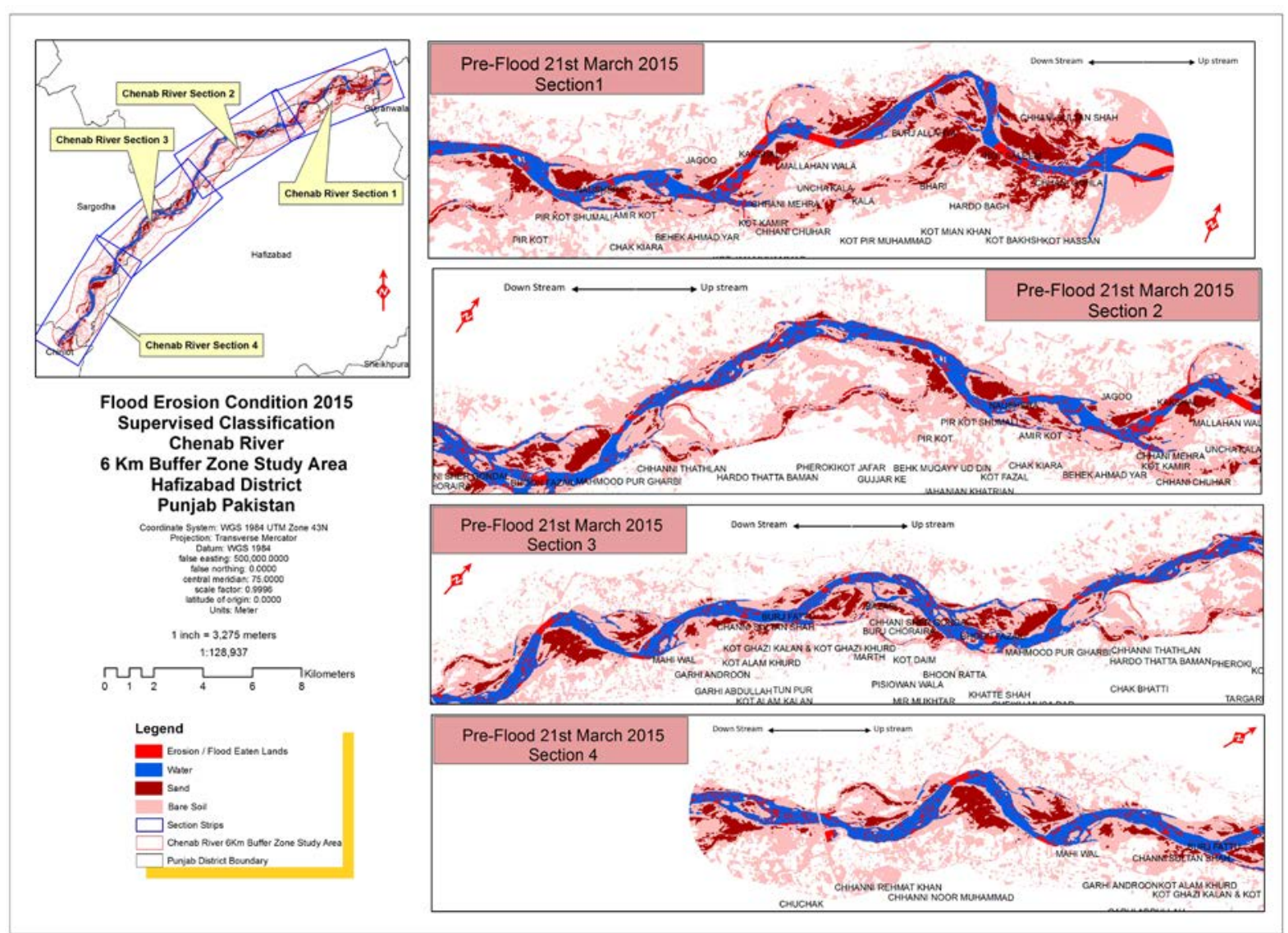

Figure 17. Flood erosion condition 2015, supervised classification, Chenab River 6 km buffer zone study area, Hafizabad District, Punjab, Pakistan.

is observed at inner side of the meandering and erosion at outer side.

\subsection{Damages Due to Water}

Water damages are significant as post-flood effect which extends economic, cultural, and social penalties. 5530.9768 acre cultivated land has gone under water in 2014 flood as shown in Table 4. It has been calculated that 3230.0374 acre land is still under water in 2015. Water damages to standing crops and human life during flood 2014 are shown in Figure 18.

\subsection{Damages Due to Silt, Bare Soil and Sand in 2014}

Chenab has carried large amount of sediments and ultimately deposited along its plain in the flood 2014 because of high water surge when it was released from Qadirabad headwork. Heavy deposition of sand, silt and bare soil have been calculated through post-flood 2014 satellite images along Chenab River as shown in the Figures 19-22. It has been observed that 9349.2148 acre land have converted into silt and 1988.9014 acre land has become sandy as shown in Table 5. Similarly, 5920.1547 acre land has gone under bare soil.

\subsection{Existing Sand, Silt and Bare Soil Deposits along Chenab River (2015 Scenario)}

Sand, Silt, and Bare Soil were deposited in the flood plain of Chenab River during 2014 flooding. Sand deposits have not yet been removed from the fertile lands because of high removal cost. It is also surveyed that one acre of land is recovered from sand after running a tractor for 130 hours. Silt deposits have damaged cultivated lands in 2014 but this deposition has increased the fertility of lands for next crop. Therefore, silt has not become a big issue in the recovery year 2015. Sand and Bare Soil concentration is as high as shown in Table 6. During flood 
Table 4. Water damages due to change of river flow direction.

$\begin{array}{ccc}\text { Supervised } & \text { Post-Flood on 26th September, 2014 } & \text { Pre Flood 21st March, 2015 } \\ \text { Classification } & \text { Cultivated Land Turned into Water } & \text { Cultivated Land Turned into Water } \\ & \mathbf{5 5 3 0 . 9 7 6 8 8 2} \text { acres } & \mathbf{3 2 3 0 . 0 3 7 4 0 9} \text { acres }\end{array}$

Table 5. Damages to cultivated lands due to silt and sand using supervised classification in acre.

\begin{tabular}{|cccc|}
\hline & \multicolumn{2}{c|}{ Post-flood on 26th September, 2014 } & Total \\
\hline Cultivated Land Turned into Silt & Cultivated Land Turned into Sand & Bare Soil & $17,258.2710$ \\
\hline 9349.214896 & 1988.901493 & 5920.154708 & $(34.3032 \%)$ \\
\hline
\end{tabular}

Table 6. Damages due to sand, bare soil and silt comparison of 2014 and 2015 in acre.

\begin{tabular}{|ccc|}
\hline & Post-Flood on 26th September, 2014 & \\
\hline Cultivated Land Turned into Silt & Cultivated Land Turned into Sand & Bare Soil \\
\hline $38,112.5266$ & 1988.9014 & 5920.1547 \\
\hline & Pre-Flood 21st March, 2015 & Bare Soil \\
\hline & Cultivated Land Still under Sand & $22,320.3972$ \\
\hline
\end{tabular}

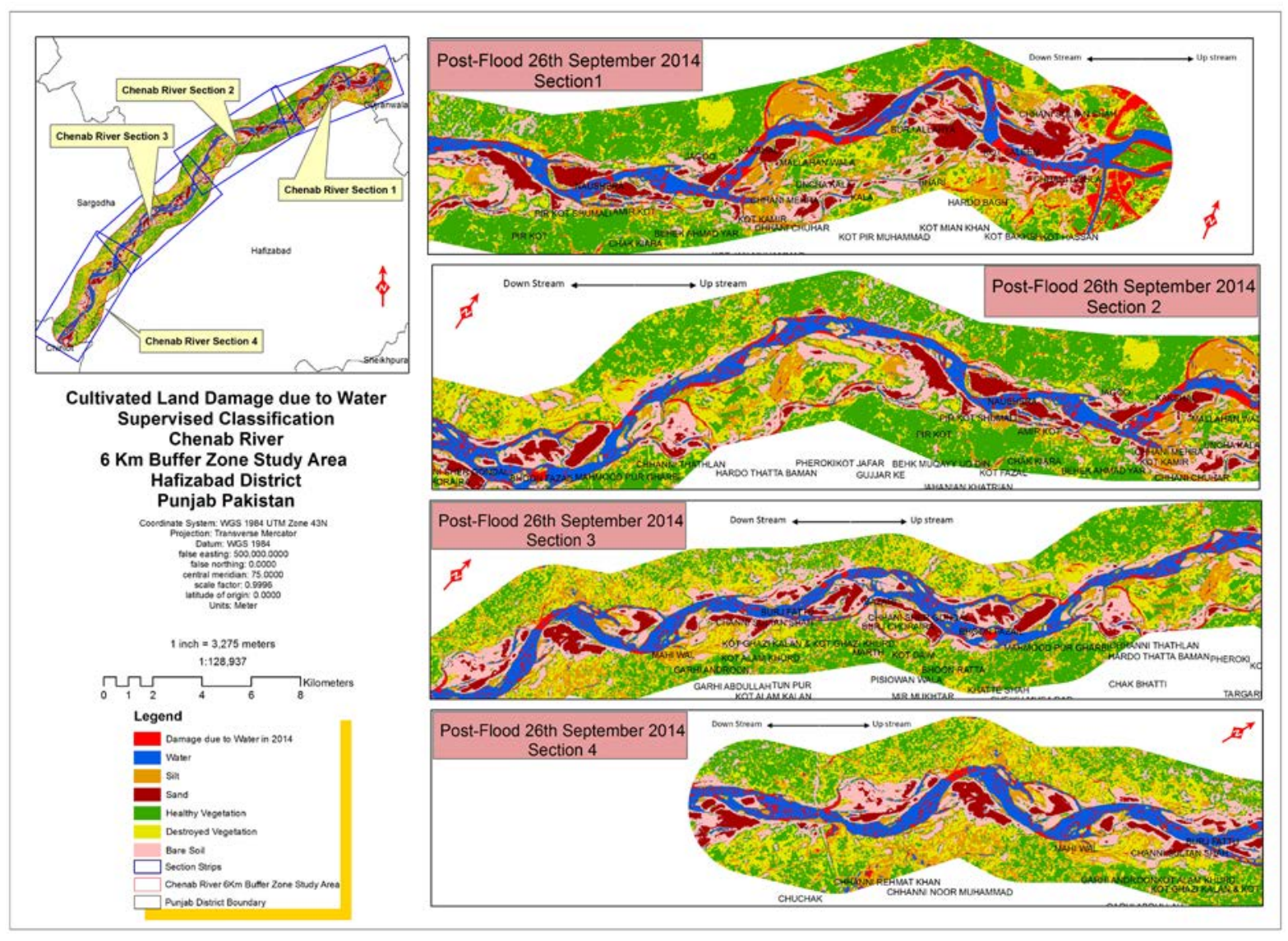

Figure 18. Cultivated land damage due to water, post-flood 2014, supervised classification, Chenab River 6 km buffer zone study area, Hafizabad District, Punjab, Pakistan. 


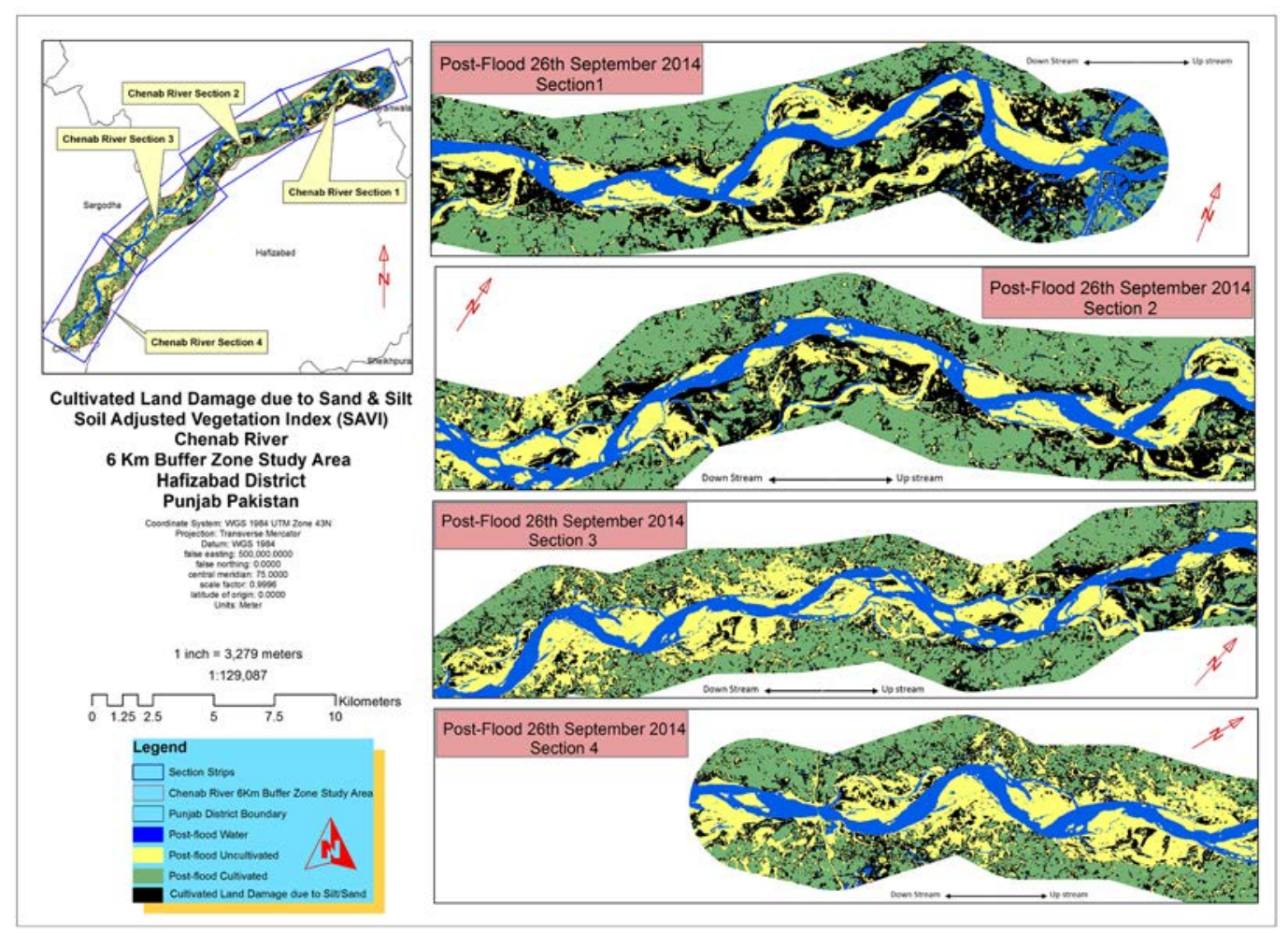

Figure 19. Cultivated land damage due to sand \& silt post-flood 2014, Soil Adjusted Vegetation Index (SAVI), Chenab River 6 km buffer zone study area, Hafizabad District, Punjab, Pakistan.

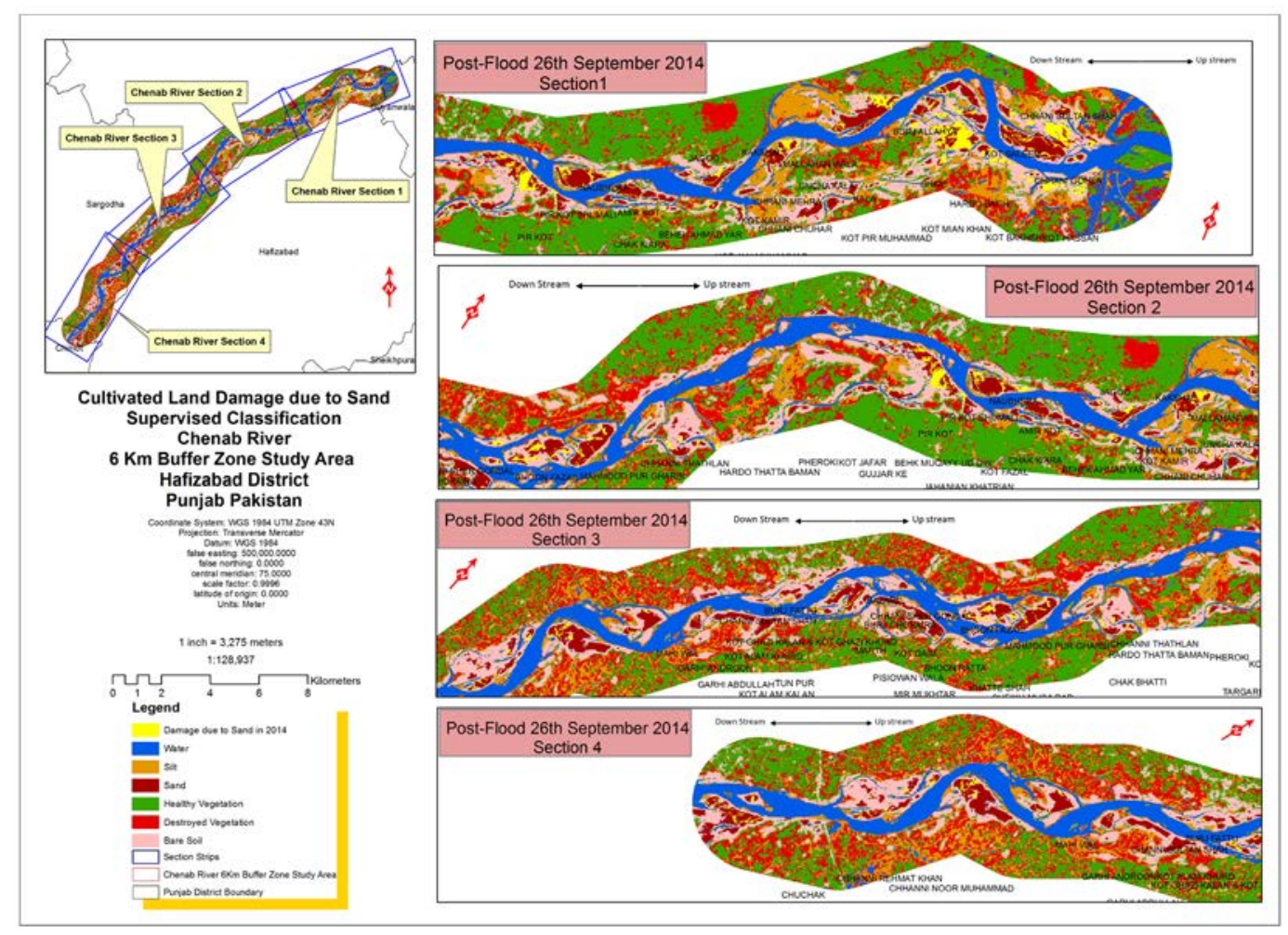

Figure 20. Cultivated land damage due to sand post-flood 2014, supervised classification, Chenab River 6 km buffer zone study area, Hafizabad District, Punjab, Pakistan. 


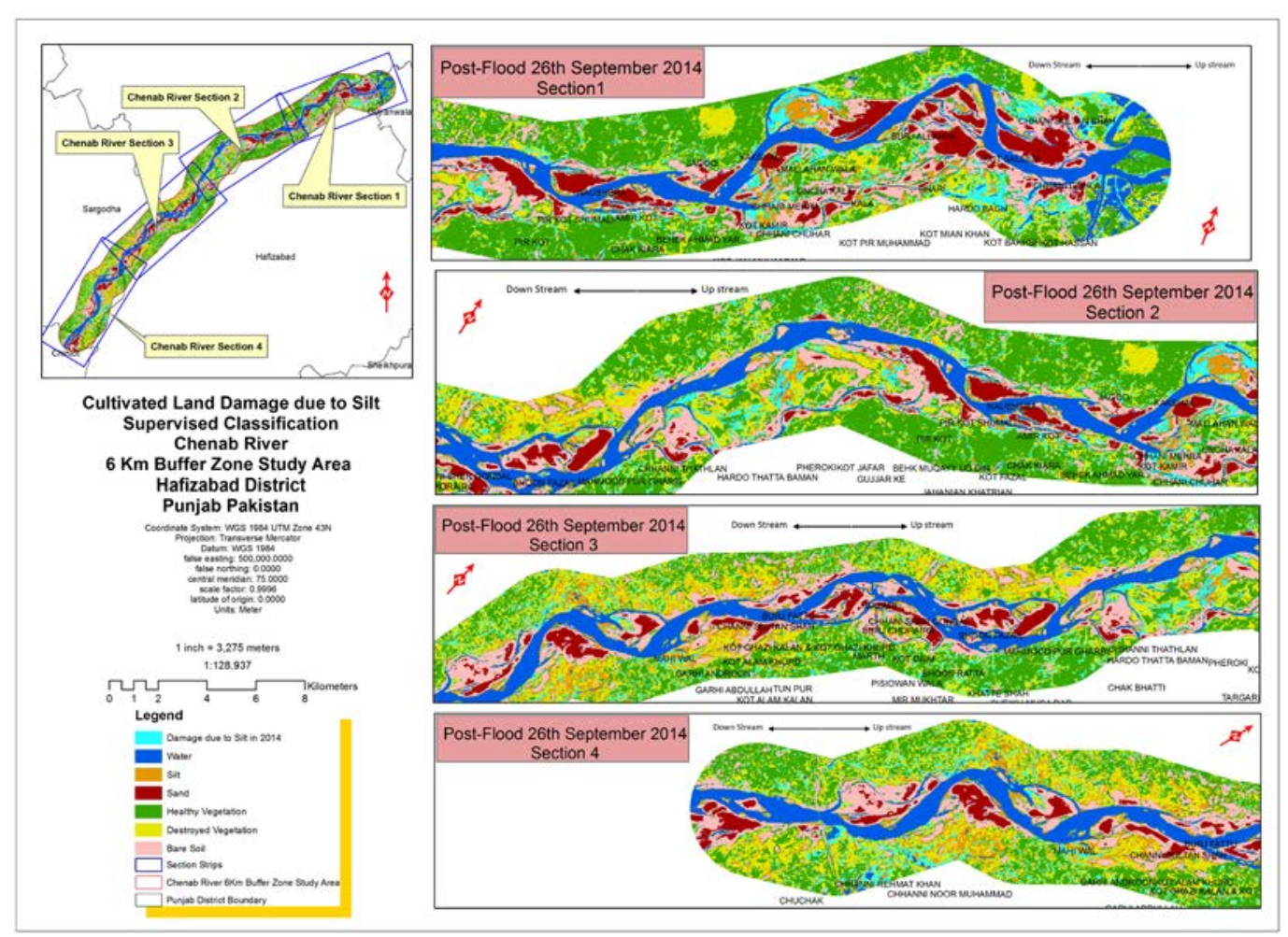

Figure 21. Cultivated land damage due to silt post-flood 2014, supervised classification, Chenab River $6 \mathrm{~km}$ buffer zone study area, Hafizabad District, Punjab, Pakistan.

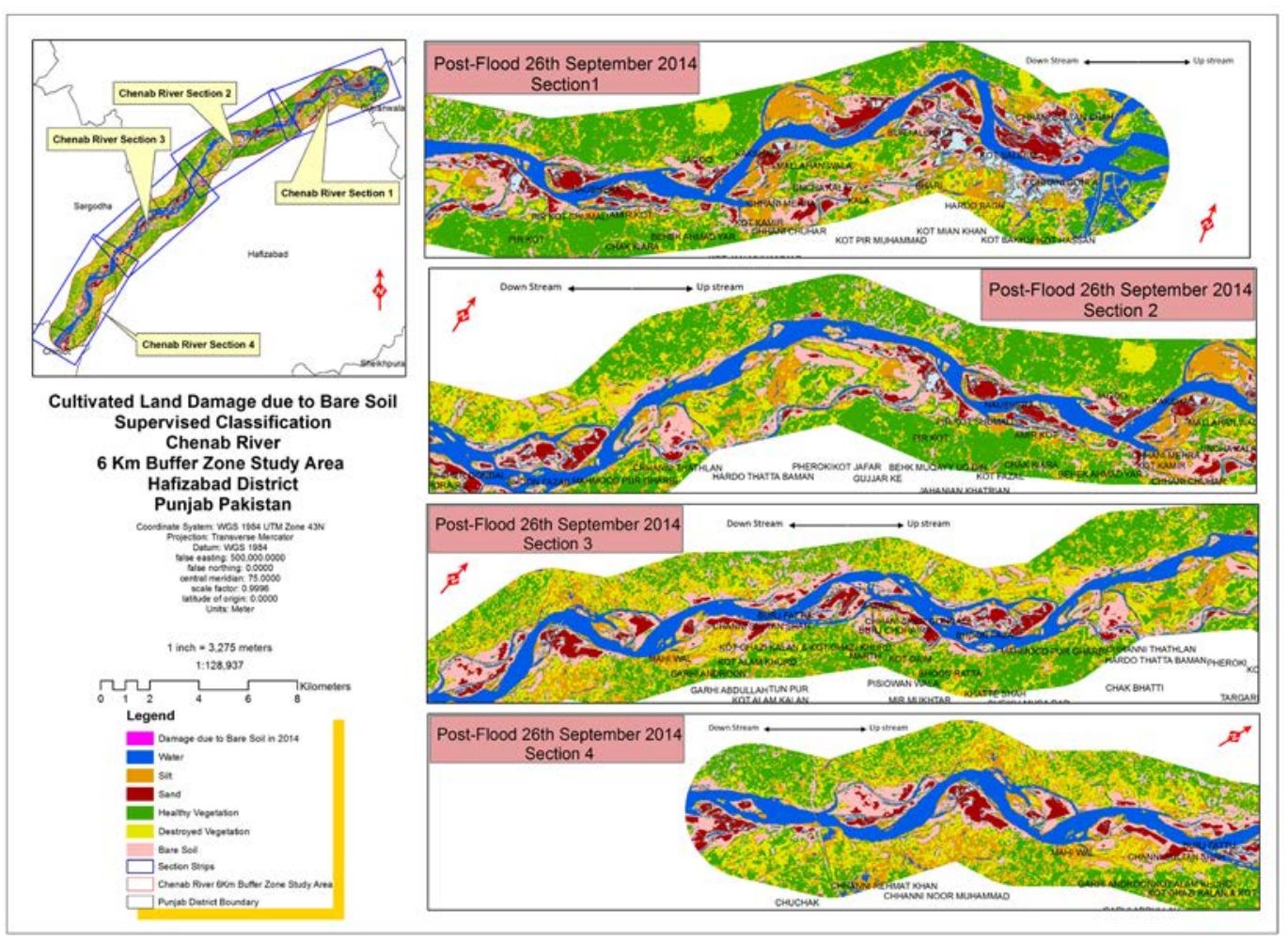

Figure 22. Cultivated land damage due to bare soil post-flood 2014, supervised classification, Chenab River $6 \mathrm{~km}$ buffer zone study area, Hafizabad District, Punjab, Pakistan. 
2014, water and silt deposits were the major damages to cultivated lands. But 2015 scenario is entirely different from the previous situation of 2014. When the water receded, deposits surfaced. SAVI and Supervised Classification results shown in Figures 23-25 indicate that the concentration of sand and bare soil is very high throughout the study area. Statistics have also shown that bare soil deposits have increased $26.5235 \%$ after the recession of water in 2015 than the flood of 2014.

\subsection{Recovery of Lands from Heavy Sand and Bare Soil Deposits}

Recovery of lands from bare soil and sand is significantly important. Farmers have reinstated 23,802.23751 acre fertile land from heavy sand and bare soil deposits shown in Table 7. Cultivated lands which were previously damaged due to water are being recovered as shown in Figure 26. Furthermore, GPS surveys have been conducted in phases along Chenab River to check the level of correlation between the recovery results of Landsat 8 data and actual situation on the ground. Surveys have given promising results and having a great correlation with satellite based recovery results. GPS surveyed recovery points have indicated that recovery sites calculated through images are valid.

\subsection{Qualitative Use and Relationship between SAVI and Supervised Classification Results}

Table 8 describes the qualitative comparison between the results of applied methodologies of this research work for the year of 2014 and 2015. Under this comparison, cultivated, uncultivated, and water situations have been correlated. Cultivated land results of pre-flood 2014, post-flood 2014, and pre-flood 2015 are having close estimations both in Supervised Classification and SAVI. There is an average deviation of $2.18 \%$ has been calculated between the results of pre-flood 2014, post-flood 2014 and pre-flood 2015 datasets for cultivated land. $2.3 \%$ average deviation for uncultivated land results and $1.9 \%$ average deviation for water.

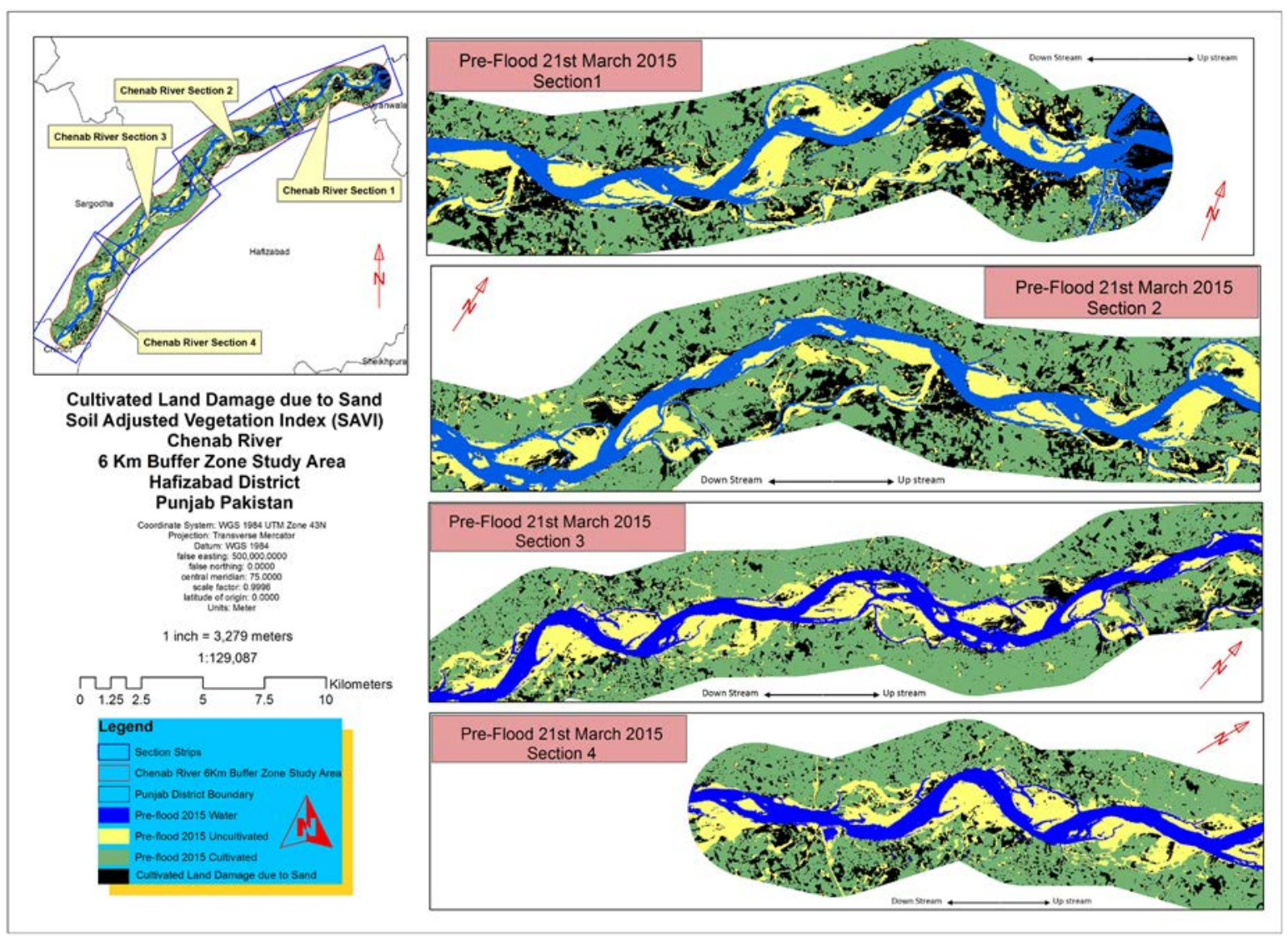

Figure 23. Cultivated land damage due to sand pre-flood 2015, Soil Adjusted Vegetation Index (SAVI), Chenab River 6 km buffer zone study area, Hafizabad District, Punjab, Pakistan. 


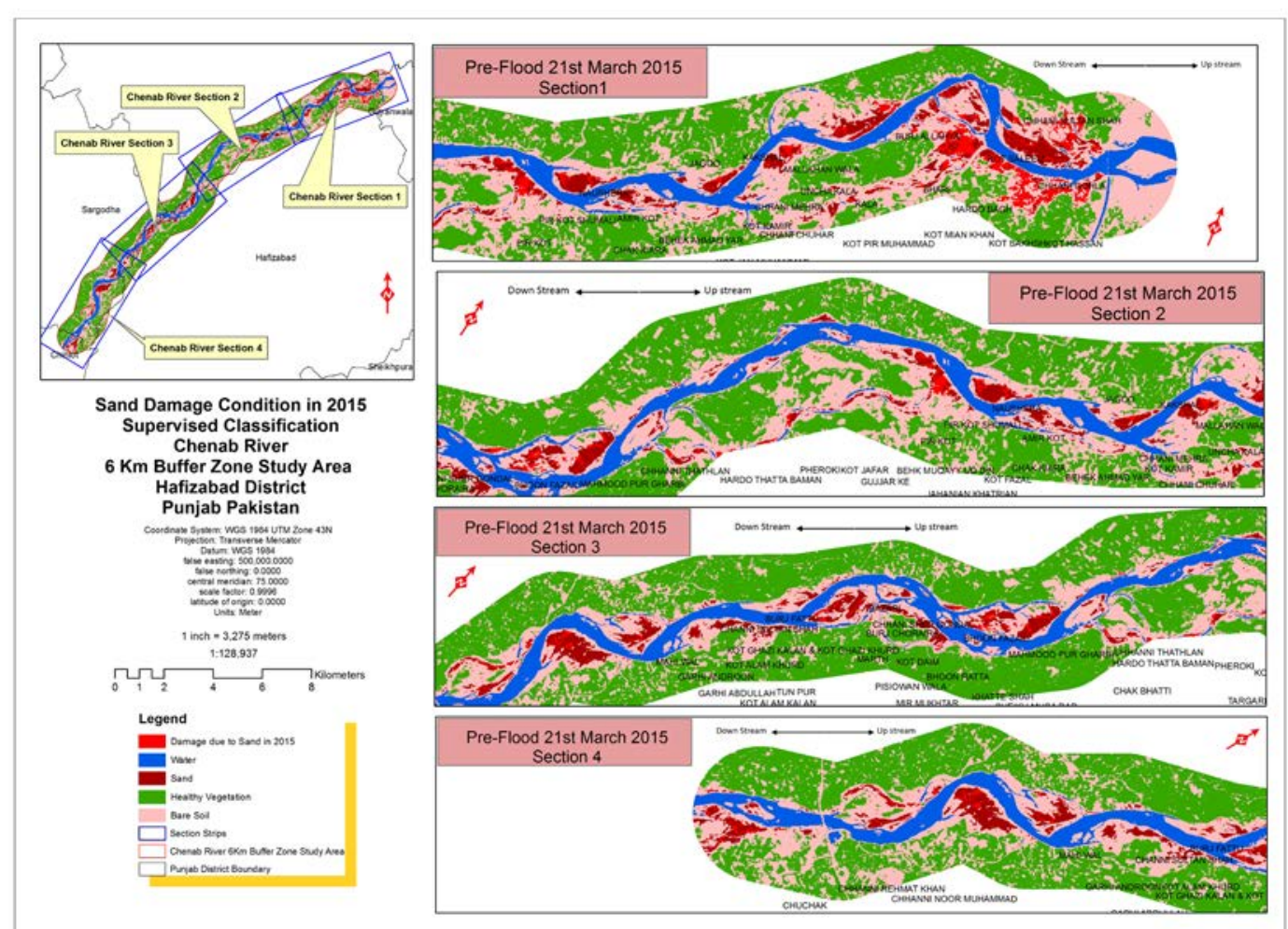

Figure 24. Cultivated land damage due to sand pre-flood 2015, Soil Adjusted Vegetation Index (SAVI), Chenab River 6 km buffer zone study area, Hafizabad District, Punjab, Pakistan.

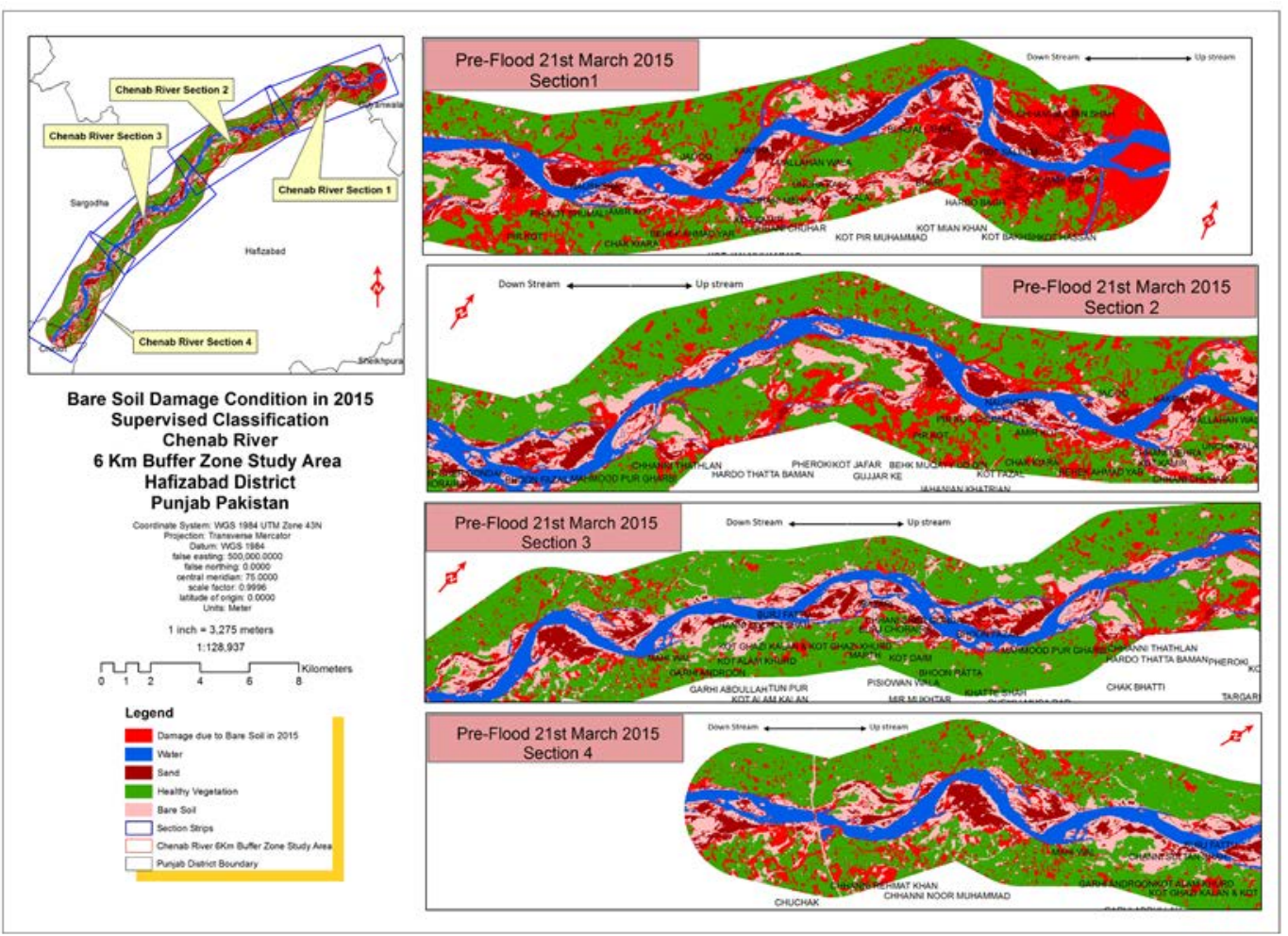

Figure 25. Bare soil damage condition in 2015 post-flood 2015, supervised classification, Chenab River 6 km buffer zone study area, Hafizabad District, Punjab, Pakistan. 


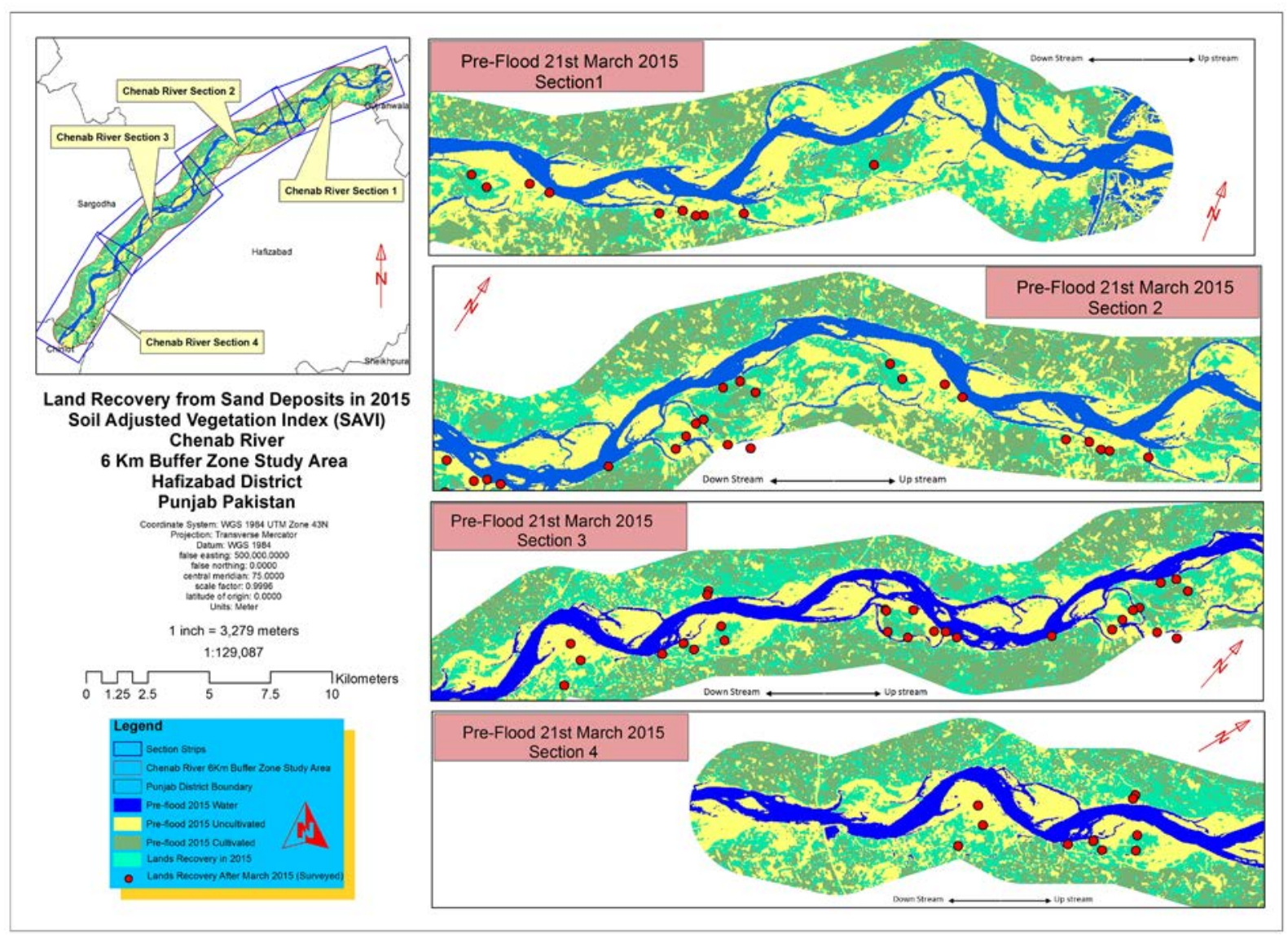

Figure 26. Survey results of land recovery from sand deposits pre-flood 2015, Soil Adjusted Vegetation Index (SAVI), Chenab River 6 km buffer zone study area, Hafizabad District, Punjab, Pakistan.

Table 7. Recovered lands from water, sand, and bare soil in acre (post-flood 2015 situation).

\begin{tabular}{cc}
\hline Total Damages & Recovered from 2014 Post Flood Damaged Land \\
\hline $38,337.04487$ & $23,802.23751$ \\
\hline
\end{tabular}

Table 8. Comparison between the results (in acre) of SAVI and supervised classification.

\begin{tabular}{|c|c|c|c|c|}
\hline Pre-Flood on 25th August, 2014 & Cultivated & Uncultivated & Water & Total \\
\hline Supervised Classification & $\begin{array}{c}70,799.37369 \\
(61.9284 \%)\end{array}$ & $\begin{array}{c}35,389.33007 \\
(30.9551 \%)\end{array}$ & $\begin{array}{c}8135.804039 \\
(7.1164 \%)\end{array}$ & $114,324.5078$ \\
\hline SAVI & $\begin{array}{c}67,685.56292 \\
(59.4106 \%)\end{array}$ & $\begin{array}{c}36,647.63607 \\
32.1672 \%\end{array}$ & $\begin{array}{c}9595.043227 \\
(8.4220 \%)\end{array}$ & $113,928.2422$ \\
\hline Deviation & $2.51 \%$ & $1.21 \%$ & $1.30 \%$ & $0.35 \%$ \\
\hline \multicolumn{5}{|l|}{ Post-Flood on 26th September, 2014} \\
\hline Supervised Classification & $\begin{array}{c}34,872.3104 \\
(30.5029 \%)\end{array}$ & $\begin{array}{c}62,765.14948 \\
(54.9008 \%)\end{array}$ & $\begin{array}{c}16,687.07342 \\
(14.5962 \%)\end{array}$ & $114,324.5333$ \\
\hline SAVI & $\begin{array}{c}38,112.52663 \\
(33.4321 \%)\end{array}$ & $\begin{array}{c}59,249.87043 \\
(51.9737 \%)\end{array}$ & $\begin{array}{c}16,637.22567 \\
(14.5941 \%)\end{array}$ & $113,999.6227$ \\
\hline Deviation & $2.92 \%$ & $2.92 \%$ & $0.0021 \%$ & $0.29 \%$ \\
\hline \multicolumn{5}{|l|}{ Pre-Flood 21st March, 2015} \\
\hline Supervised Classification & $\begin{array}{c}53,076.36591 \\
(46.4260 \%)\end{array}$ & $\begin{array}{c}48,350.80535 \\
(42.2925 \%)\end{array}$ & $\begin{array}{c}12,897.33654 \\
(11.2813 \%)\end{array}$ & $114,324.5078$ \\
\hline SAVI & $\begin{array}{c}54,178.94143 \\
(47.5593 \%)\end{array}$ & $\begin{array}{c}41,773.31404 \\
(36.6694 \%)\end{array}$ & $\begin{array}{c}17,966.37825 \\
(15.7712 \%)\end{array}$ & $113,918.6337$ \\
\hline Deviation & $1.13 \%$ & $5.6 \%$ & $4.4 \%$ & $0.36 \%$ \\
\hline
\end{tabular}




\section{Conclusion}

Hafizabad has been facing massive floods for a long time. It affects a large piece of agricultural lands every year. Sand, silt, and water have been the main causes of damages. Under this study, it has been analyzed that flood effects are extended to agricultural lands at maximum. Landsat 8 satellite images have given promising results in the monitoring and calculation of final results of damages. Pre-flood situation has indicated that there were agricultural lands along Chenab River and water was flowing at its normal level. Post-flood 2014 situation has indicated that water has changed its direction and created havoc along its banks. During flood 2014, water damages have been high. Satellite images have shown that agricultural lands have converted into barren lands due to the deposition of sediments. Pre-flood 2015 situation is clearly indicating that the water level is increasing day by day in Chenab River. Further, it has also been observed that the deposition is so high that the farmers are unable to recover their lands from sand and bare soil deposits. It has been surveyed that recovery is still under process. Lands are under recovery process at a number of sites. People are recovering lands from heavy layers of sand. However, the results, between SAVI and Supervised Classification, of this research work are having a great deal of correlation and accuracy.

\section{References}

[1] Ma, Y., Liu, X.M., Li, X.J., Sun, Y.H. and Li, X.M. (2011) Rapid Assessment of Flood Disaster Loss in Sindh and Punjab Province, Pakistan Based on RS and GIS. 2011 International Conference on Multi-Media Technology (ICMT), Hangzhou, 26-28 July 2011, 646-649.

[2] Darosh, P., Malik, S.J. and Krausova, M. (2010) Rehabilitating Agriculture and Promoting Food Security after the 2010 Pakistan Floods: Insights from the South Asian Experience. The Pakistan Development Review, 49, 167-192.

[3] Yang, C.G., Yu, Z.B., Hao, Z.C., Lin, Z.H. and Liu, S.F. (2009) Evaluation of Hydrological Response to Land Use Change at Large Scale. International Conference on Environmental Science and Information Application Technology (ESIAT), Vol. 1, Wuhan, 4-5 July 2009, 336-339. http://dx.doi.org/10.1109/ESIAT.2009.195

[4] Feizizadeh, B. and Blaschke, T. (2013) Land Suitability Analysis for Tabriz County, Iran: A Multi-Criteria Evaluation Approach Using GIS. Journal of Environment Planning and Management, 56, 1-23. http://dx.doi.org/10.1080/09640568.2011.646964

[5] Hazarika, N., Das, A.K. and Borah, S.B. (2015) Assessing Land-Use Changes Driven by River Dynamics in Chronically Flood Affected Upper Brahmaputra Plains, India, Using RS-GIS Techniques. The Egyptian Journal of Remote Sensing and Space Science, 18, 107-118.

[6] Chien, S., Doubleday, J., Mclaren, D., Tran, D., Tanpipat, V., Chitradon, R., Boonya-Aroonnet, S., Thanapakpawin, P. and Mandl, D. (2013) Monitoring Flooding in Thailand Using Earth Observing One on a Sensorweb. IEEE Journal of Selected Topics in Applied Earth Observations and Remote Sensing, 6, 291-297. http://dx.doi.org/10.1109/JSTARS.2013.2247974

[7] Akhtar, S. (2011) The South Asiatic Monsson and Flood Hazards in the Indus River Basin, Pakistan. Journal of Basic and Applied Sciences, 7, 101-115. http://dx.doi.org/10.6000/1927-5129.2011.07.02.05

[8] PDMA (2014) PDMA-Contingency-Plan-2014. PDMA, Lahore.

[9] PDMA (2013) Punjab-Disaster-Response-Plan-2013. PDMA, Lahore.

[10] Sujjak, P.L. (2010) District Hafizabad: Progress and Politics. NGO, Punjab Lok Sujjak, Lahore.

[11] Hashmi, H.N., Siddiqui, Q.T., Ghumman, A., Kamal, M.A. and Mughal, H.-U.-R. (2012) A Critical Analysis of 2010 Floods in Pakistan. African Journal of Agricultural Research, 7, 1054-1067.

[12] Weicheng, W., Ahmad, M.S., Waleed, A.-S.M., Feras, Z. and Boubakar, D. (2014) Mapping Soil Salinity Changes Using Remote Sensing in Central Iraq. Geoderma Regional, 2-3, 21-31. http://dx.doi.org/10.1016/j.geodrs.2014.09.002

[13] Pultz, T. and Scofield, R. (2002) Applications of Remotely Sensed Data in Flood Prediction and Monitoring: Report of the CEOS Disaster Management Support Group Flood Team. 2002 IEEE International Geoscience and Remote Sensing Symposium, IGARSS'02, 2, 768-770.

[14] Sivaprasad, K. and Bolus, R.L. (1994) Delineation of 1993 Midwest Flooding Using ERS-1 SAR, SPOT and Landsat Imagery. 1994 International Geoscience and Remote Sensing Symposium, Surface and Atmospheric Remote Sensing: Technologies, Data Analysis and Interpretation, IGARSS' 94, 3, 1439-1441.

[15] Du, J.K., Xie, S.P., Xu, Y.P., Xie, H., Hu, Y.J., Wang, P.F. and Hu, S.F. (2006) Flood Simulation with Distributed Hydrological Approach Using DEMs and Remotely Sensed Data. 2006 IEEE International Conference on Geoscience and Remote Sensing Symposium, IGARSS 2006, Denver, 31 July-4 August 2006, 1056-1059.

http://dx.doi.org/10.1109/igarss.2006.272 
[16] Gaillard, C., Zagolski, F. and Bonn, F. (1997) Modelling of Human Dimension on Soil Erosion Processes for Remote Sensing Applications. IGARSS'97 Symposium, 1, 122-124. http://dx.doi.org/10.1109/igarss.1997.615816

[17] Liengsakul, M., Mekpaiboonwatana, S., Pramojanee, P., Bronsveld, K. and Huizing, H. (1993) Use of GIS and Remote Sensing for Soil Mapping and for Locating New Sites for Permanent Cropland-A Case Study in the "Highlands" of Northern Thailand. Geoderma, 60, 193-307. http://dx.doi.org/10.1016/0016-7061(93)90032-G

[18] Goyari, P. (2005) Flood Damages and Sustainability of Agriculture in Assam. Economic and Political Weekly, 40, 2723-2729.

[19] Zhao, W.L., Li, F.M., Mou, Y.L., Jia, C.J. and Sun, G.J. (2010) Simulation of Farming Suitability for Arid-Agriculture Using a GIS-Evaluation Approach in the Loess Plateau, China. World Automation Congress (WAC), Kobe, 19-23 September 2010, 107-111.

[20] Satish, S., Nagendra, H. and Ravi, G. (2012) Application of Remote Sensing and GIS for Flood Risk Analysis: A Case Study of Krishna and Tungabadra River Valley. International Journal of Social Science \& Interdiscilplinary Research, 1, 50-61.

[21] Steiner, F.R. and Butler, K. (2012) Planning and Urban Design Standards. John Wiley \& Sons, Austin.

[22] Lillisand, T.M. and Kiefer, R.W. (2002) Remote Sensing and Image Interpretation. 4th Edition, John Wiley \& Sons (Asia) Pte. Ltd., Singapore.

[23] Boken, V.K., Cracknell, A.P. and Heathcote, R.L. (2005) Monitoring and Predicting Agricultural Drought. Oxford University Press, Inc., New York.

[24] Liang, S. (2004) Quantitative Remote Sensing of Land Surfaces. John Wiley \& Sons Inc., Hoboken.

[25] Huete, A.R. (1988) A Soil Adjusted Vegetation Index (SAVI). Remote Sensing of Environment, 25, 295-309. http://dx.doi.org/10.1016/0034-4257(88)90106-X 